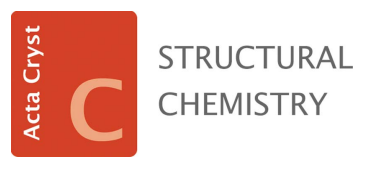

ISSN 2053-2296

Received 17 October 2016

Accepted 14 November 2016

Edited by A. L. Spek, Utrecht University, The Netherlands

Keywords: DL-norvaline; maleic acid; amino acid salt; hydrogen bond; crystal structure; crystal engineering.

CCDC references: $1517422 ; 1519878$

Supporting information: this article has supporting information at journals.iucr.org/C

\section{New 1:1 and 2:1 salts in the 'DL-norvaline-maleic acid' system as an example of assembling various crystal structures from similar supramolecular building blocks}

\author{
Sergey G. Arkhipov, ${ }^{a, b *}$ Evgeniy A. Losev $^{a, b}$ and Elena V. Boldyreva ${ }^{b}$
}

${ }^{\mathbf{a}}$ Novosibirsk State University Pirogova str. 2, Novosibirsk 630090, Russian Federation, and ${ }^{\mathbf{b}}$ Institute of Solid State Chemistry and Mechanochemistry SB RAS, Kutateladze str. 18, Novosibirsk 630128, Russian Federation. *Correspondence e-mail: arksergey@gmail.com

Molecular salts and cocrystals of amino acids have potential applications as molecular materials with nonlinear optical, ferroelectric, piezoelectric, and other various target physical properties. The wide choice of amino acids and coformers makes it possible to design various crystal structures. The amino acid-maleic acid system provides a perfect example of a rich variety of crystal structures with different stoichiometries, symmetries and packing motifs built from the molecular building blocks, which are either exactly the same, or differ merely by protonation or as optical isomers. The present paper reports the crystal structures of two new salts of the DL-norvaline-maleic acid system with 1:1 and 2:1 stoichiometries, namely DL-norvalinium hydrogen maleate, $\mathrm{C}_{5} \mathrm{H}_{12} \mathrm{NO}_{2}{ }^{+}$.$\mathrm{C}_{4} \mathrm{H}_{3} \mathrm{O}_{4}{ }^{-}$, (I), and DL-norvalinium hydrogen maleate-DL-norvaline, $\mathrm{C}_{5} \mathrm{H}_{12^{-}}$ $\mathrm{NO}_{2}{ }^{+} \cdot \mathrm{C}_{4} \mathrm{H}_{3} \mathrm{O}_{4}{ }^{-} \cdot \mathrm{C}_{5} \mathrm{H}_{11} \mathrm{NO}_{2}$, (II). These are the first examples of molecular salts of DL-norvaline with an organic anion. The crystal structure of (I) has the same $C_{2}^{2}(12)$ structure-forming motif which is common for hydrogen maleates of amino acids. The structure of (II) has dimeric cations. Of special interest is that the single crystals of (I) which are originally formed on crystallization from aqueous solution transform into single crystals of (II) if stored in the mother liquor for several hours.

\section{Introduction}

Molecular salts and cocrystals of amino acids are interesting mostly due to their potential applications as molecular materials with optical, piezoelectric, ferroelectric and other target physical properties (Fleck \& Petrosyan, 2014). For example, large (several millimetres in each direction) crystals of L-alaninium hydrogen maleate $\left[\left(\mathrm{L}-\mathrm{AlaH}^{+}\right) \cdot \mathrm{M}^{-}\right]$(Alagar et al., $2001 b)$, L-argininium hydrogen maleate dihydrate $\left[\left(\mathrm{L}-\mathrm{ArgH}^{+}\right) \cdot-\right.$ $\left.M^{-} \cdot 2 \mathrm{H}_{2} \mathrm{O}\right]$ (Sun et al., 2007), L-phenylalaninium hydrogen maleate $\left[\left(\mathrm{L}-\mathrm{PheH}^{+}\right) \cdot M^{-}\right]$(Alagar et al., 2001c), L-histidinium hydrogen maleate hydrate $\left[\left(\mathrm{L}-\mathrm{HisH}^{+}\right) \cdot M^{-} \cdot \mathrm{H}_{2} \mathrm{O}\right]$ (Fleck et al., 2013), L-methioninium L-methionine hydrogen maleate $\left(\mathrm{L}-\mathrm{Met} \cdot \mathrm{L}-\mathrm{MetH}^{+} \cdot M^{-}\right)$(Natarajan et al., 2010) and glycinium hydrogen maleate $\left[\left(\mathrm{GlyH}^{+}\right) \cdot M^{-}\right]$(Alagar et al., 2001a) were obtained and the second harmonic generation (SHG) efficiency, investigated using the Kurtz-Perry powder method (Kurtz \& Perry, 1968), was 0.27-1.5 times that of the SGH efficiency of KDP (potassium dideuterium phosphate) (Anbuchezhiyan et al., 2009; Devaprasad \& Madhavan, 2010; Yogam et al., 2012; Gonsago et al., 2012; Vasudevan et al., 2013; Charoen-In et al., 2010; Balasubramanian et al., 2010; Natarajan et al., 2008). The wide choice of amino acids and coformers makes it possible to design various crystal structures that 
Table 1

Experimental details.

(I)

Crystal data

Chemical formula

$M_{\mathrm{r}}$

Crystal system, space group

Temperature $(\mathrm{K})$

$a, b, c(\AA)$

$\alpha, \beta, \gamma\left(^{\circ}\right)$

$V\left(\AA^{3}\right)$

Z

Radiation type

$\mu\left(\mathrm{mm}^{-1}\right)$

Crystal size (mm)

Data collection

Diffractometer

Absorption correction

$T_{\min }, T_{\max }$

No. of measured, independent and observed

$[I>2 \sigma(I)]$ reflections

$R_{\text {int }}$

$(\sin \theta / \lambda)_{\max }\left(\AA^{-1}\right)$

Refinement

$R\left[F^{2}>2 \sigma\left(F^{2}\right)\right], w R\left(F^{2}\right), S$

No. of reflections

No. of parameters

No. of restraints

$\mathrm{H}$-atom treatment

$\Delta \rho_{\max }, \Delta \rho_{\min }\left(\mathrm{e} \AA^{-3}\right)$

(II)

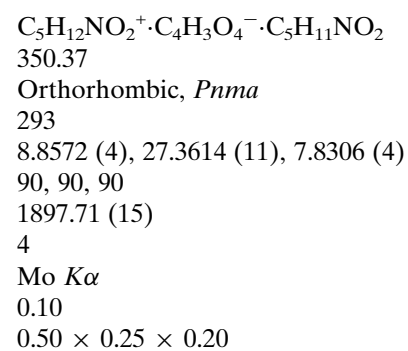

Agilent Xcalibur Ruby Gemini ultra

Multi-scan (CrysAlis PRO; Agilent, 2014)

$0.866,1.000$

13186, 2198, 1807

0.051

0.595

Agilent Xcalibur Ruby Gemini ultra

Multi-scan (CrysAlis PRO; Rigaku OD, 2015)

$0.948,1.000$

21923, 1975, 1731

0.053

0.625

$\begin{array}{ll}0.068,0.166,1.23 & 0.079,0.146,1.14 \\ 2198 & 1975 \\ 169 & 216 \\ 12 & 298 \\ \text { H-atom parameters constrained } & \text { H atoms treated by a mixture of independent } \\ & \text { and constrained refinement } \\ 0.25,-0.15 & 0.15,-0.20\end{array}$

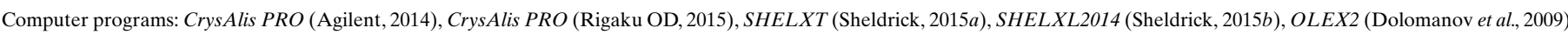
and Mercury (Macrae et al., 2008).

could be potentially important from a crystal engineering point of view. Moreover, in all the solvates of this system, in particular, hydrates can form on crystallization.<smiles>CCCC([NH3+])C(=O)O</smiles><smiles>O=C(O)/C=C\C(=O)O</smiles>

(I)<smiles>CCC[C@H]([NH3+])C(=O)[CH]OC(=O)[C@@H]([NH3+])CCC</smiles><smiles>O=C(O)/C=C\C(=O)O</smiles>

(II)

In addition to the abovementioned nonlinear optical properties, the 'amino acid-maleic acid' system provides a perfect example of a molecular salt in which the same small organic coformer (maleic acid) can cocrystallize with a large variety of molecules (amino acids). Maleic acid donates a proton to the amino acid and is present as a small and rigid maleate anion in all the crystalline maleates of amino acids. These structures can have various stoichiometries. The diversity of the stoichiometric ratios is determined by several factors:

(i) the symmetry non-equivalence of several amino acid cations; (ii) the charge of the side chain of the amino acid;

(iii) the binding of several amino acid cations and zwitterions to form complex subunits known as dimeric or trimeric cations.

In particular, it is important to compare the crystal structures of chiral and racemic amino acid salts and cocrystals. Crystals of L- and DL-amino acids often have radically different properties (Chesalov et al., 2008; Kolesov \& Boldyreva, 2007; Bordallo et al., 2007; Kolesnik et al., 2005), and the same may hold for their salts and cocrystals (Boldyreva, 2014; Arkhipov et al., 2013). Recently, the crystal structure of L-norvalinium hydrogen maleate-L-norvaline has been analyzed and shown to have dimeric $\mathrm{L}-\mathrm{Nva} \cdot \mathrm{L}_{\mathrm{L}}-\mathrm{NvaH}^{+}$ cations (Arkhipov et al., 2015). In the present paper, we report the structures of racemic salts formed by DL-norvaline and maleic acid having different stoichiometries, namely DL-norvalinium hydrogen maleate, (I), and DL-norvalinium hydrogen maleate-DL-norvaline, (II).

\section{Experimental}

\subsection{Synthesis and crystallization}

Crystals of (I) were obtained by slow evaporation at room temperature from a drop of the saturated aqueous solution containing DL-norvaline and maleic acid in a 1:1 ratio (Rychkov et al., 2014). Interestingly, crystallization from an 
Table 2

Classification of hydrogen maleates according to their stoichiometry.

There are also two hydrates belonging to the $A^{+} B^{-}$class, viz. $\left(\mathrm{L}^{-} \mathrm{ArgH}^{+}\right)$-$M^{-} \cdot 2 \mathrm{H}_{2} \mathrm{O}$ (CSD refcode GIHGEK; Sun et al., 2007) and $\left(\mathrm{L}-\mathrm{HisH}^{+}\right) \cdot M^{-} \cdot \mathrm{H}_{2} \mathrm{O}$ (CSD refcode TENVUF; Fleck et al., 2013), and two other hydrates related to the $n A^{+} n B^{-}$class, viz. (L$\left.\mathrm{HisH}^{+}\right)_{2} \cdot\left(M^{-}\right)_{2} \cdot 3 \mathrm{H}_{2} \mathrm{O}\left(\mathrm{CSD}\right.$ refcode VAZJUD; Gonsago et al., 2012) and $\left(\mathrm{L}-\mathrm{IleH} \mathrm{H}^{+}\right)_{2} \cdot\left(M^{-}\right)_{2} \cdot \mathrm{H}_{2} \mathrm{O}$ (CSD refcode VUKQEZ; Arkhipov et al., 2015).

\begin{tabular}{|c|c|c|c|}
\hline Composition & $\begin{array}{l}\text { Stoichiometry } \\
\text { class }\end{array}$ & $\begin{array}{l}\text { Numerical } \\
\text { order }\end{array}$ & $\begin{array}{l}\text { CSD refcodes and references } \\
\text { to original work }\end{array}$ \\
\hline $\begin{array}{l}\left(\mathrm{GlyH}^{+}\right) \cdot M^{-} \\
\left(\mathrm{L}-\mathrm{AlaH}^{+}\right) \cdot M^{-} \\
\left(\mathrm{L}-\mathrm{PheH}^{+}\right) \cdot M^{-} \\
\left(\mathrm{DL}-\mathrm{PheH}^{+}\right) \cdot M^{-} \\
\left(\mathrm{DL}-\mathrm{ValH}^{+}\right) \cdot M^{-} \\
\left(\mathrm{L}-\mathrm{SerH}^{+}\right) \cdot M^{-} \\
\left(\mathrm{DL}-\mathrm{SerH}^{+}\right) \cdot M^{-} \\
\left(\mathrm{DL}-\mathrm{MetH}^{+}\right) \cdot M^{-} \\
\left(\mathrm{SarH}{ }^{+}\right) \cdot M^{-} \\
\left(\mathrm{L}-\mathrm{ValH}^{+}\right) \cdot M^{-} \\
\left(\mathrm{DL}-\mathrm{ThrH}^{+}\right) \cdot M^{-} \\
\left(\beta-\mathrm{AlaH}^{+}\right) \cdot M^{-} \\
\left(\mathrm{BacH}^{+}\right) \cdot M^{-} \\
\left(\mathrm{L}-\mathrm{LysH}^{+}\right) \cdot M^{-} \\
\left(\mathrm{DL}-\mathrm{ArgH}^{+}\right) \cdot M^{-} \\
\left(\mathrm{BetH}^{+}\right) \cdot M^{-}\end{array}$ & $A^{+} B^{-}$ & 1 & $\begin{array}{l}\text { RENBAN (Rajagopal } \text { et al., 2001a) } \\
\text { BOQTEG (Alagar } \text { et al., 2001b) } \\
\text { EDAXIQ (Alagar } \text { et al., 2001c) } \\
\text { VAGVIJ (Alagar } \text { et al., 2003) } \\
\text { QURSUR (Alagar } \text { et al., 2001a) } \\
\text { REZPET (Arkhipov } \text { et al., 2013) } \\
\text { REZPAP (Arkhipov } \text { et al., 2013) } \\
\text { MOCXUX (Alagar } \text { et al., 2002) } \\
\text { MIYBAX01 (Ilczyszyn } \text { et al., 2003) } \\
\text { NUZMIG (Rychkov } \text { et al., 2016) } \\
\text { ETEYOR (Rajagopal } \text { et al., 2004) } \\
\text { EDASUX (Rajagopal } \text { et al., 2001b) } \\
\text { LUSXII (Báthori \& Kilinkissa, 2015) } \\
\text { XADTOL (Pratap et al., 2000) } \\
\text { Ravishankar } \text { et al. (1998) } \\
\text { NASQED01 (Haussühl \& Schreuer, } \\
\text { 2001) }\end{array}$ \\
\hline $\begin{array}{l}\left(\mathrm{L}-\mathrm{HisH}_{2}^{2+}\right) \cdot\left(M^{-}\right)_{2} \\
\mathrm{~L}-\mathrm{Met} \cdot \mathrm{L}-\mathrm{MetH}^{+} \cdot M^{-} \\
\mathrm{L}-\mathrm{Nva} \cdot \mathrm{L}-\mathrm{NvaH} \mathrm{H}^{+} \cdot M^{-} \\
\left(\mathrm{L}-\mathrm{HisH}{ }^{+}\right)_{2} \cdot\left(M^{-}\right)_{2} \\
\left(\mathrm{~L}-\mathrm{LeuH}^{+}\right)_{3} \cdot\left(M^{-}\right)_{3}\end{array}$ & $\begin{array}{l}A^{n+} n B^{-} \\
A_{2}^{+} B^{-} \\
n A^{+} n B^{-}(n=2,3, \text { etc. })\end{array}$ & $\begin{array}{l}2 \\
3\end{array}$ & $\begin{array}{l}\text { TENVOZ (Fleck et al., 2013) } \\
\text { Natarajan } \text { et al. }(2010) \\
\text { VUKQID (Arkhipov et al., 2015) } \\
\text { XADTIF (Pratap et al., 2000) } \\
\text { VUKQAV (Arkhipov et al., 2015) }\end{array}$ \\
\hline
\end{tabular}

liquor for a few hours, are transformed into larger crystals of another phase, denoted (II), with a 2:1 stoichiometry of DL-norvaline and maleic acid. One can suppose that phase (I) nucleates and grows faster than phase (II), although the latter is the thermodynamically more stable form. The case is very similar to that observed when crystallizing tolazamide polymorphs (I) and (II) (Boldyreva et al., 2015), as well as to other solution-assisted polymorphic transformations (Munroe et al., 2014; Kobari et al., 2014). The crystals of (II), grown from a small drop were thin and not suitable for single-crystal X-ray structural analysis. Larger crystals of (II) were obtained using slow evaporation from a crystallization vessel.

\subsection{Crystal structure solution and refine- ment}

Crystal data, data collection and structure refinement details are summarized in Table 1. Suitable crystals of (I) and (II) was selected under a microscope in polarized light and mounted by means of MiTeGen MicroGrippers using MiTeGen LV Cryo Oil

equimolar drop of the solution of DL-norvaline and maleic acid first gives crystals of (I), which, if kept in the mother
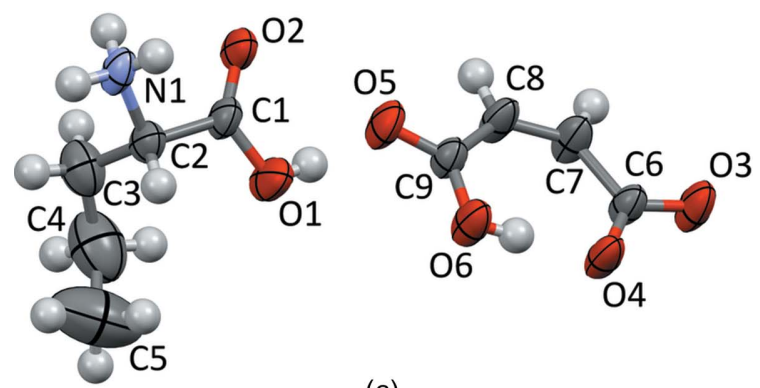

(a)
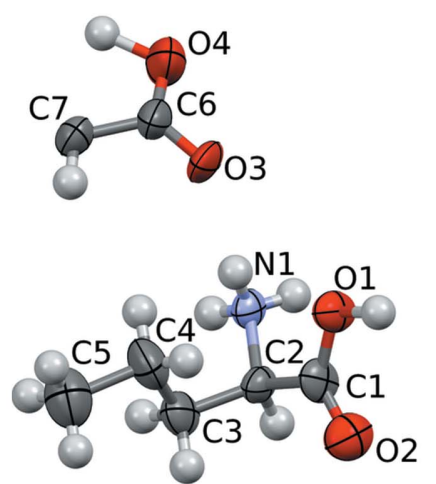

(b)

Figure 1

The asymmetric units of $(a)$ (I) and (b) (II), showing the atom-numbering schemes. Displacement ellipsoids are drawn at the $50 \%$ probability level. For (I), only the major-disorder form of the molecules are shown. For (II), half of the maleate anion belongs to the asymmetric unit, as it sits on a mirror plane.
(LVCO-1) on an Agilent Xcalibur diffractometer. The $n$ propyl group (including the $\mathrm{H}$ atoms) of the DL-norvalinium cation of the structure of (I) $(\mathrm{C} 4 A / \mathrm{C} 5 A)$ is disordered (the minor-disorder sites are labelled $\mathrm{C} 4 B / \mathrm{C} 5 B$ ). The occupation ratio of the disordered sites refined to 0.865 (8):0.135 (8). For the $\mathrm{C} 5 \mathrm{~B} / \mathrm{C} 4 \mathrm{~B} / \mathrm{C} 3$ atoms, the $U^{i j}$ values were restrained to be within $0.02 \AA^{2}$ (within $0.04 \AA^{2}$ for the terminal atom). All $\mathrm{H}$ atoms were located initially in a difference Fourier map. The positions of all $\mathrm{H}$ atoms were subsequently geometrically optimized and refined using a riding model, with the following assumptions and constraints: $\mathrm{N}-\mathrm{H}=0.89 \AA, \mathrm{O}-\mathrm{H}=0.82 \AA$ and $\mathrm{C}-\mathrm{H}=0.93$ (anion), 0.98 (methine), 0.97 (methylene) or $0.96 \AA$ (methyl), with $U_{\text {iso }}(\mathrm{H})=1.5 U_{\text {eq }}$ (parent atom) for the methyl and $\mathrm{OH}$ groups, and $1.2 U_{\text {eq }}$ (parent atom) otherwise.

The selection of a good-quality single crystal of (I) was not easy because the brittle crystals were easily damaged. The crystal eventually selected for the X-ray diffraction experiment contained four domains. Data reduction was carried out in three different ways: (i) taking into account the reflections from the largest domain only (one orientation matrix and 59\% of all reflections); (ii) processing the diffraction data as from a multiple crystal (four different orientation matrices) using reflections from all four domains; (iii) processing the diffraction data as from a multiple crystal using four different orientation matrices but taking into consideration the reflection from largest domain (50\% of all reflections). According to the $F^{2} / \sigma\left(F^{2}\right)$ and $R_{\text {int }}$ parameters, the first method gave the best results.

All atoms of (II) (except for the $\mathrm{C}$ atom of the carboxyl group of the maleate anion, the $\mathrm{H}$ atom of the carboxyl group 


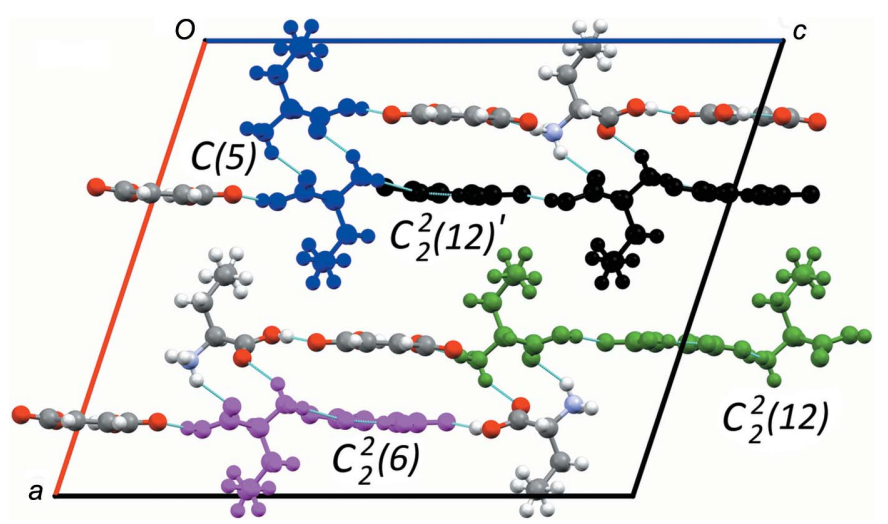

Figure 2

The crystal structure of fragments of (I), showing $(a) C_{2}^{2}(12)$ chains linked to each other via $C_{2}^{2}(6)$ chains and $(b) C_{2}^{2}(12)^{\prime}$ chains linked to each other via $C(5)$ chains.

of the dimeric DL-norvalinium-DL-norvaline cation and another $\mathrm{H}$ atom of the carboxyl group of the maleate anion) are disordered. The sites with smaller occupancies are defined as $B$. The occupancy ratio for the disordered sites was refined as $0.556(11): 0.444(11)$ for the maleate anion and 0.741 (5):0.259 (5) for the dimeric DL-norvalinium-DL-norvaline cation. The amino acid cations at the sites with higher and lower occupancies are stereoisomers. The $\mathrm{H} 1$ atom lies on the inversion centre and the $\mathrm{H} 4$ atom lies on the mirror plane; therefore, the corresponding site occupancies are equal to 0.5 . The $\mathrm{C} 1 B-\mathrm{C} 2 B, \mathrm{O} 1 B-\mathrm{C} 1 B, \mathrm{O} 1-\mathrm{H} 1$ and $\mathrm{O} 4-\mathrm{H} 4$ distances were fixed at 1.480 (2), 1.400 (2), 1.289 (2) and 1.202 (2) $\AA$, respectively. The anisotropic displacement parameters of all the atoms were refined with a rigid-bond restraint. For all non$\mathrm{H}$ atoms, the $U^{i j}$ values were restrained to be within $0.04 \AA^{2}$ (within $0.08 \AA^{2}$ for the terminal atom). All $\mathrm{H}$ atoms were located initially in a difference Fourier map. The positions of all $\mathrm{H}$ atoms (except for the $\mathrm{H} 1$ and $\mathrm{H} 4$ atoms, for which $\mathrm{O}-\mathrm{H}$ distances were restrained) were subsequently geometrically optimized and refined using a riding model, with the following assumptions and constraints: $\mathrm{N}-\mathrm{H}=0.89 \AA$ and $\mathrm{C}-\mathrm{H}=0.93$ (anion), 0.98 (methine), 0.97 (methylene) or $0.96 \AA$ (methyl), with $U_{\text {iso }}(\mathrm{H})=1.5 U_{\text {eq }}(\mathrm{C}, \mathrm{O})$ for the methyl and $\mathrm{OH}$ groups, and $1.2 U_{\text {eq }}(\mathrm{C}, \mathrm{N})$ otherwise.

\section{Results and discussion}

Currently, 25 crystal structures of molecular salts of maleic acid with amino acids have been reported, with 23 having been documented in the Cambridge Structural Database (CSD; Groom et al., 2016) and two structures having no refcodes [DL-argininium hydrogen maleate (Ravishankar et al., 1998) and L-methioninium L-methionine hydrogen maleate (Natarajan et al., 2010)]. All these structures can be divided into three classes.

(1) Hydrogen maleates with a 1:1 stoichiometry containing one amino acid and one maleate anion in the asymmetric unit. The majority of all known hydrogen maleates belong to this class.

(2) Hydrogen maleates with a 1:2 stoichiometry containing one amino acid dication and two maleate anions in the asymmetric unit. Currently only one structure can be assigned to this class (see Table 2, refcode TENVOZ).

(3) Hydrogen maleates with dimeric amino acid cations and maleate anions consequently having a 2:1 stoichiometry.

(4) Hydrogen maleates with a 1:1 stoichiometry containing more than one of each chemical species (amino acid cation and maleate anion) in the asymmetric unit (Table 2).

The title salts, (I) and (II), are the first examples of molecular salts of DL-norvaline with a carboxylic acid (Fig. 1). Maleic acid is known as a common coformer. Due to its compact flat shape, stabilized by an intramolecular hydrogen bond (Table 3 ) and the presence of several hydrogen-bond acceptors, maleic acid can easily be embedded into different crystalline environments. Salt (I) crystallizes in the centrosymmetric space group $C 2 / c$. The asymmetric unit of (I) contains one norvaline cation and one maleate anion, so that it
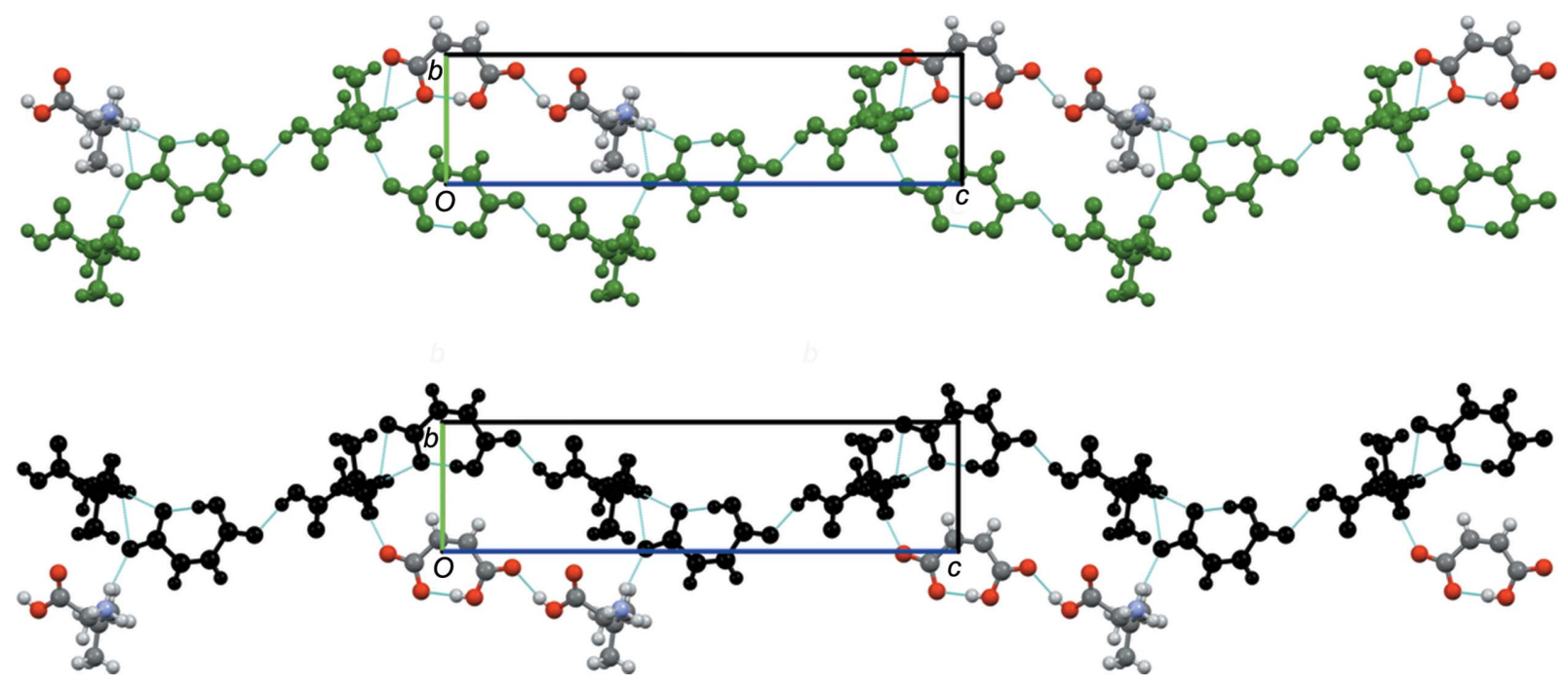

$C_{2}^{2}(12)^{\prime}$

Figure 3

The $C_{2}^{2}(12)$ and $C_{2}^{2}(12)^{\prime}$ chains in $\left(\mathrm{DL}-\mathrm{NvaH}^{+}\right) \cdot M^{-},(\mathrm{I})$. 


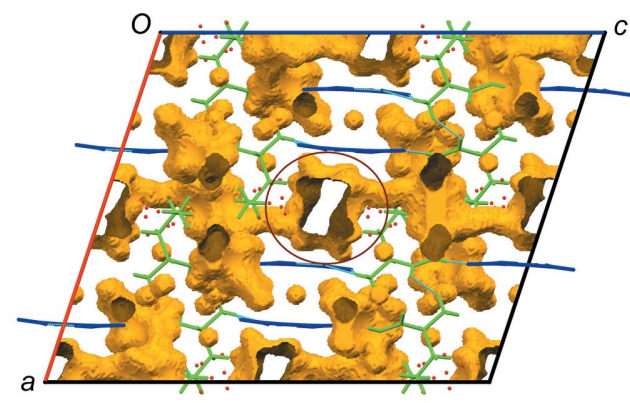

(a)

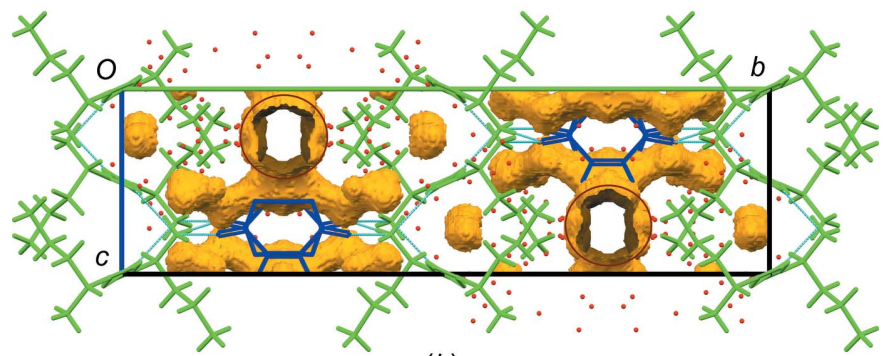

(b)

Figure 4

Visualization of the voids in the structures of $(a)$ (I) and (b) (II) using the Mercury program (Macrae et al., 2008). The channel along the $b$ direction is highlighted by the dark-red circle. Voids were found using the "contact surface' method with a probe radius of $0.5 \AA$ and a grid size of $0.1 \AA$. The major-disorder form of the DL-norvalinium cation and DL-norvaliniumDL-norvaline dimeric cation are coloured green, the maleate anion is blue and red dots correspond to the minor-disorder forms of the components.

belongs to the first (most populated) class of the aforementioned classification (Fig. 1) (Table 2).

The crystal structure of (I) can be compared with those of two polymorphs of pure DL-norvaline, i.e. at 203 (the $\beta$-form) and $183 \mathrm{~K}$ (the $\alpha$-form) (Görbitz, 2011). Both compounds have layered structures; the $\mathrm{H}_{3} \mathrm{~N}^{+}$group of the norvaline zwitterions are linked to three $\mathrm{COO}^{-}$groups of other zwitterions by hydrogen bonds, forming three 'head-to-tail' chains. Similar chains (but composed of norvalinium cations) are present also in the structure of (I) $[C(5)$ motifs along the crystallographic $b$ direction]. One can also see $C_{2}^{2}(6)$ chains along the $b$ direction formed by hydrogen bonds between the $\mathrm{NH}_{3}{ }^{+}$group of one norvalinium cation and the $\mathrm{COO}^{-}$group of another cation (Fig. 2 and Table 4). Almost all the amino acid maleates contain $C_{2}^{2}(12)$ chains (Rychkov et al., 2016), and (I) is no exception; it also has $C_{2}^{2}(12)$ chains formed by norvalinium cations and maleate anions assembling along the $c$ direction. In addition, there are $C_{2}^{2}(12)^{\prime}$ chains in (I) formed by two types of hydrogen bonds: (i) between the $\mathrm{COOH}$ group of a norvalinium cation and the $\mathrm{COOH}$ group of a maleate anion, and (ii) between the $\mathrm{H}_{3} \mathrm{~N}^{+}$group of a norvalinium cation and the $\mathrm{COO}^{-}$group of a maleate anion (Fig. 3). The second type of hydrogen bond involves one of the $\mathrm{O}$ atoms of the $\mathrm{COO}^{-}$group of a maleate anion which is participating in an intramolecular hydrogen bond within a maleate anion (Fig. 3 and Table 3). The $C_{2}^{2}(6), C_{2}^{2}(12)$ and $C_{2}^{2}(12)^{\prime}$ chains form half a layer, and two such half-layers are connected by $C(5)$ chains, with each forming a complete layer so that a twodimensional hydrogen-bonding network parallel to the (100)
Table 3

Hydrogen-bond geometry $\left(\AA,^{\circ}\right)$ for $(\mathrm{I})$.

\begin{tabular}{lllll}
\hline$D-\mathrm{H} \cdots A$ & $D-\mathrm{H}$ & $\mathrm{H} \cdots A$ & $D \cdots A$ & $D-\mathrm{H} \cdots A$ \\
\hline $\mathrm{O} 6-\mathrm{H} 6 \cdots \mathrm{O} 4$ & 0.82 & 1.60 & $2.421(2)$ & 178 \\
$\mathrm{O} 1-\mathrm{H} 1 \cdots \mathrm{O} 5$ & 0.82 & 1.80 & $2.612(3)$ & 171 \\
$\mathrm{~N} 1-\mathrm{H} 1 A \cdots \mathrm{O} 2^{\mathrm{i}}$ & 0.89 & 2.11 & $2.864(3)$ & 142 \\
$\mathrm{~N} 1-\mathrm{H} 1 B \cdots \mathrm{O} 4^{\mathrm{ii}}$ & 0.89 & 2.01 & $2.898(3)$ & 172 \\
$\mathrm{~N} 1-\mathrm{H} 1 C \cdots \mathrm{O} 3^{\text {iii }}$ & 0.89 & 1.97 & $2.850(3)$ & 168
\end{tabular}

Symmetry codes: (i) $-x+\frac{1}{2}, y+\frac{1}{2},-z+\frac{3}{2}$; (ii) $x,-y+1, z+\frac{1}{2}$; (iii) $x,-y, z+\frac{1}{2}$.

Table 4

Hydrogen-bond geometry $\left(\AA{ }^{\circ}\right)$ for (II).

\begin{tabular}{lllll}
\hline$D-\mathrm{H} \cdots A$ & $D-\mathrm{H}$ & $\mathrm{H} \cdots A$ & $D \cdots A$ & $D-\mathrm{H} \cdots A$ \\
\hline $\mathrm{N} 1-\mathrm{H} 1 A \cdots \mathrm{O} 2^{\mathrm{i}}$ & 0.89 & 1.94 & $2.807(8)$ & 165 \\
$\mathrm{~N} 1-\mathrm{H} 1 B \cdots \mathrm{O} 3$ & 0.89 & 2.08 & $2.92(4)$ & 157 \\
$\mathrm{~N} 1-\mathrm{H} 1 C \cdots 3^{\mathrm{ii}}$ & 0.89 & 1.90 & $2.79(4)$ & 178 \\
$\mathrm{O} 1-\mathrm{H} 1 \cdots \mathrm{O} 1^{\text {iii }}$ & $1.28(1)$ & $1.28(1)$ & $2.568(13)$ & $180(1)$ \\
$\mathrm{O}^{\text {iv }}-\mathrm{H} 4 \cdots 4^{\text {iv }}$ & $1.21(1)$ & $1.21(1)$ & $2.418(9)$ & $173(8)$ \\
\hline
\end{tabular}

Symmetry codes: (i) $-x+\frac{1}{2},-y+1, z-\frac{1}{2}$; (ii) $x-\frac{1}{2}, y,-z+\frac{1}{2}$; (iii) $-x+1,-y+1$, $-z+1$; (iv) $x,-y+\frac{3}{2}, z$.

plane is formed (Fig. 2). The side chains of DL-norvaline are directed to the outer surfaces of the layers and thus adjacent layers interdigitate to give hydrophobic layers with welldefined channels lie parallel to the hydrophobic layers (Fig. 4).

The molecular salt (II) crystallizes in a centrosymmetric Pnma space group. The unit cell of (II) contains dimeric DLnorvalinium-DL-norvaline cations (a zwitterion of norvaline and a norvalinium cation connected by a strong $\mathrm{O}-\mathrm{H} \cdots \mathrm{O}$ hydrogen bond) and maleate anions in the 1:1 ratio. The salt (II) could be assigned to the third class according to Table 2. The structure of (II) contains two $C_{3}^{3}(17)$ heteromolecular chains along the crystallographic $b$ direction formed by dimeric DL-norvalinium-DL-norvaline cations and maleate anions. Similar hydrogen-bonded chains were observed in the structure of L-norvalinium hydrogen maleate-L-norvaline (Arkhipov et al., 2015) (Fig. 5a). Head-to-tail $C(5)$ chains of dimeric DL-norvalinium-DL-norvaline cations propagate along the $c$ direction normal to the $C_{3}^{3}(17)$ chains. Another amino acid $C_{2}^{2}(9)$ chain along the $a$ direction is formed by the dimeric DL-norvalinium-DL-norvaline cations. These three types of chains have common norvaline molecules and are connected with each other by hydrogen bonds to form a three-dimensional hydrogen-bonded network. Comparing the structures of (I) and (II), one can see that the same components form different types of crystal structures: a layered structure in (I) and a three-dimensional hydrogen-bonded structure in (II). The structure of (II) also has channels along the crystallographic $a$ direction; the volume of the voids in (II) $(12.1 \%$, $230.42 \AA^{3}$ ) is about a half of that in (I) (Fig. 4).

The DL-norvaline-maleic acid system is interesting from a crystal engineering point of view: the same molecules form salts with different types of crystal structures. DL-Norvaline can form salts with maleic acid with either a layered structure as in (I) or a three-dimensional hydrogen-bonded structure as in (II). The molecular salts (I) and (II) belong to different stoichiometric classes (Table 2). DL-Norvalinium hydrogen 


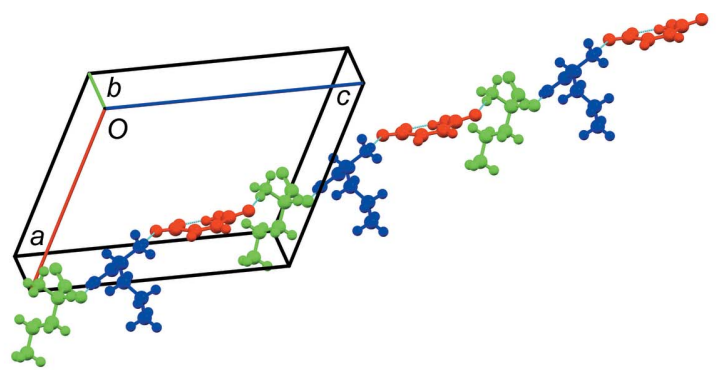

(a)

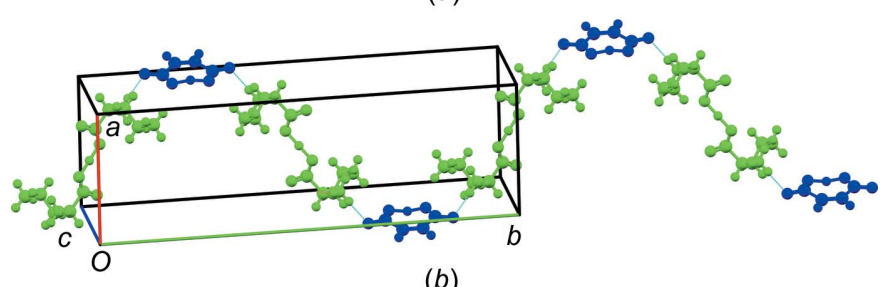

(b)

Figure 5

Comparison of the heteromolecular hydrogen-bonded chains in the structures of $(a)$ L-norvalinium hydrogen maleate-L-norvaline (Arkhipov et al., 2015) and (b) DL-norvalinium hydrogen maleate-DL-norvaline, (II).

maleate, (I), and DL-norvalinium hydrogen maleate-DL-norvaline, (II), are the first examples of molecular salts of DLnorvaline with a carboxylic acid. The presence of the dimeric cation of DL-norvaline in the structure of (II) makes it possible to form a three-dimensional network of hydrogen bonds, the structural type which is not common for the maleates of amino acids with a large hydrophobic side chain. Despite the large number of hydrogen maleates documented in the literature, the prediction of whether a selected L-amino acid or a DLracemate will cocrystallize with maleic acid is still difficult to make. For example, for norvaline, both L- and DL-norvalinium hydrogen maleates (with different stoichiometries) have been reported (Arkhipov et al., 2015). For alanine, only L-alaninium hydrogen maleate has been described (Alagar et al., 2001a), with no maleates of the racemic DL-form reported. In contrast, for threonine, DL-threoninium hydrogen maleate exists (Rajagopal et al., 2004), but no maleate of the L-form has been reported. Moreover, the crystallization of DL-alaninium hydrogen maleate is probably impossible because of the resolution of alanine enantiomers in a racemic solution on addition of maleic acid with the formation of L-alaninium hydrogen maleate and D-alaninium hydrogen maleate (Asai et al., 1975). Such 'stereoselective' cocrystallization is hard to explain using the traditional synthon approach (Desiraju, 1995). It is quite possible that the number of hydrogen maleates of amino acids obtained is proportional to the time spent searching for them, similar to what McCrone (1965) supposed for polymorphs.

Another interesting point related to the hydrogen maleates of L-amino acids is the presence of dimeric cations in some of the structures. Up to now, this complex structural subunit has been observed in two hydrogen maleates of amino acids, namely in L-norvalinium hydrogen maleate-L-norvaline (Arkhipov et al., 2015) and in L-methioninium L-methionine hydrogen maleate (Natarajan et al., 2010). DL-Norvalinium hydrogen maleate-DL-norvaline, (II), is the first example of a racemic maleate containing the dimeric cation of an amino acid.

\section{Acknowledgements}

This work was supported by a grant from the Ministry of Education and Science of Russia (project 1828) (SGA), and by RFBR (grant No. 16-33-60089 mol_a_dk) (to EAL).

\section{References}

Agilent (2014). CrysAlis PRO. Agilent Technologies Ltd, Yarnton, Oxfordshire, England.

Alagar, M., Krishnakumar, R. V., Mostad, A. \& Natarajan, S. (2001a). Acta Cryst. E57, o1102-o1104.

Alagar, M., Krishnakumar, R. V., Nandhini, M. S. \& Natarajan, S. (2001b). Acta Cryst. E57, o855-o857.

Alagar, M., Krishnakumar, R. V. \& Natarajan, S. (2001c). Acta Cryst. E57, o968-o970.

Alagar, M., Subha Nandhini, M., Krishnakumar, R. V., Mostad, A. \& Natarajan, S. (2003). Acta Cryst. E59, o209-o211.

Alagar, M., Subha Nandhini, M., Krishnakumar, R. V. \& Natarajan, S. (2002). Acta Cryst. E58, o396-o398.

Anbuchezhiyan, M., Ponnusamy, S. \& Muthamizhchelvan, C. (2009). Spectrochim. Acta Part A, 74, 917-923.

Arkhipov, S. G., Rychkov, D. A., Pugachev, A. M. \& Boldyreva, E. V. (2015). Acta Cryst. C71, 584-592.

Arkhipov, S. G., Zakharov, B. A. \& Boldyreva, E. V. (2013). Acta Cryst. C69, 517-521.

Asai, S., Tazuke, H. \& Kageyama, H. (1975). US Patent 3897484A; Appl. No. 239786.

Balasubramanian, D., Murugakoothan, P. \& Jayavel, R. (2010). J. Cryst. Growth, 312, 1855-1859.

Báthori, N. B. \& Kilinkissa, O. E. Y. (2015). CrystEngComm, 17, 8264-8272.

Boldyreva, E. V. (2014). Z. Kristallogr., 229, 236-245.

Boldyreva, E. V., Arkhipov, S. G., Drebushchak, T. N., Drebushchak, V. A., Losev, E. A., Matvienko, A. A., Minkov, V. S., Rychkov, D. A., Seryotkin, Y. V., Stare, J. \& Zakharov, B. A. (2015). Chem. Eur. J. 21, 15395-15404.

Bordallo, H. N., Kolesov, B. A., Boldyreva, E. V. \& Juranyi, F. (2007). J. Am. Chem. Soc. 129, 10984-10985.

Charoen-In, U., Ramasamy, P. \& Manyum, P. (2010). J. Cryst. Growth, 312, 2369-2375.

Chesalov, Yu. A., Chernobay, G. B. \& Boldyreva, E. V. (2008). J. Struct. Chem. 49, 627-638.

Desiraju, G. R. (1995). Angew. Chem. Int. Ed. Engl. 34, 2311-2327.

Devaprasad, S. A. \& Madhavan, J. (2010). Arch. Appl. Sci. Res. 2, 5056.

Dolomanov, O. V., Bourhis, L. J., Gildea, R. J., Howard, J. A. K. \& Puschmann, H. (2009). J. Appl. Cryst. 42, 339-341.

Fleck, M., Ghazaryan, V. V., Bezhanova, L. S., Atanesyan, A. K. \& Petrosyan, A. M. (2013). J. Mol. Struct. 1035, 407-415.

Fleck, M. \& Petrosyan, A. M. (2014). In Salts of Amino Acids. Crystallization, Structure and Properties. Cham, Switzerland: Springer International Publishing.

Gonsago, C. A., Albert, H. M., Karthikeyan, J., Sagayaraj, P. \& Pragasam, A. J. A. (2012). Mater. Res. Bull. 47, 1648-1652.

Görbitz, C. H. (2011). J. Phys. Chem. B, 115, 2447-2453.

Groom, C. R., Bruno, I. J., Lightfoot, M. P. \& Ward, S. C. (2016). Acta Cryst. B72, 171-179.

Haussühl, E. \& Schreuer, J. (2001). Z. Kristallogr. 216, 616-622.

Ilczyszyn, M., Godzisz, D. \& Ilczyszyn, M. (2003). Spectrochim. Acta A Mol. Biomol. Spectrosc. 59, 1815-1828.

Kobari, M., Kubota, N. \& Hirasawa, I. (2014). CrystEngComm, 16, 6049-6058. 
Kolesnik, E. N., Goryajnov, S. V. \& Boldyreva, E. V. (2005). Dokl. Akad. Nauk, 404, 61-64.

Kolesov, B. A. \& Boldyreva, E. V. (2007). J. Phys. Chem. B, 111, 14387-14397.

Kurtz, S. K. \& Perry, T. T. (1968). J. Appl. Phys. 39, 3798-3813.

Macrae, C. F., Bruno, I. J., Chisholm, J. A., Edgington, P. R., McCabe, P., Pidcock, E., Rodriguez-Monge, L., Taylor, R., van de Streek, J. \& Wood, P. A. (2008). J. Appl. Cryst. 41, 466-470.

McCrone, W. C. (1965). Polymorphism, in Physics and Chemistry of the Organic Solid State, Vol. 2, edited by D. Fox, M. M. Labes \& A. Weissberger, pp. 725-767. New York: Wiley Interscience.

Munroe, A., Croker, D. M., Rasmuson, A. C. \& Hodnett, B. K. (2014). Cryst. Growth Des. 14, 3466-3471.

Natarajan, S., Devi, N. R., Britto Dhas, S. D. M. \& Athimoolam, S. (2008). Sci. Technol. Adv. Mater. 9, 025012.

Natarajan, S., Devi, N. R., Dhas, S. A. M. B. \& Athimoolam, S. (2010). J. Optoelectron. Adv. Mater. 4, 516-519.

Pratap, J. V., Ravishankar, R. \& Vijayan, M. (2000). Acta Cryst. B56, 690-696.

Rajagopal, K., Krishnakumar, R. V., Mostad, A. \& Natarajan, S. (2001a). Acta Cryst. E57, o751-o753.
Rajagopal, K., Krishnakumar, R. V. \& Natarajan, S. (2001b). Acta Cryst. E57, o922-o924.

Rajagopal, K., Ramachandran, E., Mostad, A. \& Natarajan, S. (2004). Acta Cryst. E60, o386-0388.

Ravishankar, R., Chandra, N. R. \& Vijayan, M. (1998). J. Biomol. Struct. Dyn. 15, 1093-1100.

Rigaku OD (2015). CrysAlis PRO. Rigaku Oxford Diffraction Ltd, Yarnton, Oxfordshire, England.

Rychkov, D. A., Arkhipov, S. G. \& Boldyreva, E. V. (2014). J. Appl. Cryst. 47, 1435-1442.

Rychkov, D., Arkhipov, S. \& Boldyreva, E. (2016). Acta Cryst. B72, 160-163.

Sheldrick, G. M. (2015a). Acta Cryst. A71, 3-8.

Sheldrick, G. M. (2015b). Acta Cryst. C71, 3-8.

Sun, Z.-H., Yu, W.-T., Fan, J.-D., Xu, D. \& Wang, X.-Q. (2007). Acta Cryst. E63, o2805-02807.

Vasudevan, P., Sankar, S. \& Gokul Raj, S. (2013). Optik (Stuttgart), 124, 4155-4158.

Yogam, F., Vetha Potheher, I., Vimalan, M., Jeyasekaran, R., Rajesh Kumar, T. \& Sagayaraj, P. (2012). Spectrochim. Acta Part A, 95, 369-373. 


\section{supporting information}

Acta Cryst. (2017). C73, 13-19 [https://doi.org/10.1107/S2053229616018271]

New 1:1 and 2:1 salts in the 'DL-norvaline-maleic acid' system as an example of assembling various crystal structures from similar supramolecular building blocks

\section{Sergey G. Arkhipov, Evgeniy A. Losev and Elena V. Boldyreva}

Computing details

Data collection: CrysAlis PRO (Agilent, 2014) for (I); CrysAlis PRO (Rigaku OD, 2015) for 2dl_nv_mal. Cell refinement: CrysAlis PRO (Agilent, 2014) for (I); CrysAlis PRO (Rigaku OD, 2015) for 2dl_nv_mal. Data reduction: CrysAlis PRO (Agilent, 2014) for (I); CrysAlis PRO (Rigaku OD, 2015) for 2dl_nv_mal. For both compounds, program(s) used to solve structure: SHELXT (Sheldrick, 2015a); program(s) used to refine structure: SHELXL2014 (Sheldrick, 2015b). Molecular graphics: OLEX2 (Dolomanov et al., 2009) for (I); Mercury (Macrae et al., 2008) for 2dl_nv_mal. For both compounds, software used to prepare material for publication: OLEX2 (Dolomanov et al., 2009).

(I) DL-Norvalinium hydrogen maleate

Crystal data

$\mathrm{C}_{5} \mathrm{H}_{12} \mathrm{NO}_{2}{ }^{+} \cdot \mathrm{C}_{4} \mathrm{H}_{3} \mathrm{O}_{4}^{-}$

$M_{r}=233.22$

Monoclinic, $C 2 / c$

$a=19.6385(15) \AA$

$b=5.62705(18) \AA$

$c=23.6867$ (10) $\AA$

$\beta=108.283(6)^{\circ}$

$V=2485.4(2) \AA^{3}$

$Z=8$

Data collection

Agilent Xcalibur Ruby Gemini ultra diffractometer

Radiation source: Enhance (Mo) X-ray Source

Graphite monochromator

Detector resolution: 10.3457 pixels $\mathrm{mm}^{-1}$

$\omega$ scans

Absorption correction: multi-scan

(CrysAlis PRO; Agilent, 2014)

$T_{\min }=0.866, T_{\max }=1.000$

\section{Refinement}

Refinement on $F^{2}$

Least-squares matrix: full

$R\left[F^{2}>2 \sigma\left(F^{2}\right)\right]=0.068$

$w R\left(F^{2}\right)=0.166$
$F(000)=992$

$D_{\mathrm{x}}=1.247 \mathrm{Mg} \mathrm{m}^{-3}$

Mo $K \alpha$ radiation, $\lambda=0.71073 \AA$

Cell parameters from 3032 reflections

$\theta=1.8-25.1^{\circ}$

$\mu=0.11 \mathrm{~mm}^{-1}$

$T=293 \mathrm{~K}$

Block, clear light colourless

$0.25 \times 0.15 \times 0.1 \mathrm{~mm}$

13186 measured reflections

2198 independent reflections

1807 reflections with $I>2 \sigma(I)$

$R_{\text {int }}=0.051$

$\theta_{\max }=25.0^{\circ}, \theta_{\min }=1.8^{\circ}$

$h=-23 \rightarrow 23$

$k=-6 \rightarrow 6$

$l=-28 \rightarrow 28$

$S=1.23$

2198 reflections

169 parameters

12 restraints 
Primary atom site location: dual

Hydrogen site location: inferred from neighbouring sites

$\mathrm{H}$-atom parameters constrained

$$
\begin{aligned}
& w=1 /\left[\sigma^{2}\left(F_{\mathrm{o}}^{2}\right)+(0.0688 P)^{2}+1.2674 P\right] \\
& \text { where } P=\left(F_{\mathrm{o}}^{2}+2 F_{\mathrm{c}}{ }^{2}\right) / 3 \\
& (\Delta / \sigma)_{\max }<0.001 \\
& \Delta \rho_{\max }=0.25 \mathrm{e} \AA^{-3} \\
& \Delta \rho_{\min }=-0.15 \mathrm{e} \AA^{-3}
\end{aligned}
$$

Special details

Geometry. All esds (except the esd in the dihedral angle between two 1.s. planes) are estimated using the full covariance

\begin{tabular}{|c|c|c|c|c|c|}
\hline & $x$ & $y$ & $z$ & $U_{\text {iso }} * / U_{\text {eq }}$ & Occ. $(<1)$ \\
\hline $\mathrm{O} 2$ & $0.30316(12)$ & $0.1684(3)$ & $0.75497(7)$ & $0.0587(6)$ & \\
\hline $\mathrm{O} 4$ & 0.33415 (13) & $0.3088(3)$ & $0.45870(8)$ & $0.0634(6)$ & \\
\hline O6 & $0.34166(13)$ & $0.3563(3)$ & $0.56205(8)$ & $0.0653(6)$ & \\
\hline H6 & 0.3388 & 0.3428 & 0.5269 & $0.098 *$ & \\
\hline O5 & $0.33741(12)$ & $0.1258(4)$ & $0.63532(8)$ & $0.0640(6)$ & \\
\hline $\mathrm{O} 3$ & $0.32140(14)$ & 0.0195 & $0.39432(8)$ & $0.0733(7)$ & \\
\hline $\mathrm{O} 1$ & $0.35365(15)$ & $0.4538(4)$ & $0.71650(9)$ & $0.0797(8)$ & \\
\hline H1 & 0.3461 & 0.3614 & 0.6884 & $0.120^{*}$ & \\
\hline N1 & $0.29849(14)$ & $0.4474(4)$ & $0.84537(9)$ & $0.0530(6)$ & \\
\hline $\mathrm{H} 1 \mathrm{~A}$ & 0.2541 & 0.4754 & 0.8218 & $0.064^{*}$ & \\
\hline H1B & 0.3073 & 0.5355 & 0.8781 & $0.064 *$ & \\
\hline $\mathrm{H} 1 \mathrm{C}$ & 0.3030 & 0.2943 & 0.8553 & $0.064^{*}$ & \\
\hline $\mathrm{C} 9$ & $0.33889(16)$ & 0.1511 & $0.58407(10)$ & $0.0472(7)$ & \\
\hline $\mathrm{C} 1$ & $0.33256(16)$ & $0.3576(5)$ & $0.75847(11)$ & $0.0493(7)$ & \\
\hline C6 & $0.32998(17)$ & $0.0889(5)$ & $0.44513(11)$ & $0.0517(7)$ & \\
\hline $\mathrm{C} 2$ & $0.35023(16)$ & $0.5090(5)$ & $0.81368(11)$ & $0.0513(7)$ & \\
\hline $\mathrm{H} 2$ & 0.3446 & 0.6770 & 0.8022 & $0.062 *$ & \\
\hline $\mathrm{C} 8$ & $0.33796(19)$ & $-0.0648(5)$ & $0.54893(11)$ & $0.0602(9)$ & \\
\hline $\mathrm{H} 8$ & 0.3401 & -0.2063 & 0.5697 & $0.072 *$ & \\
\hline $\mathrm{C} 7$ & $0.33452(19)$ & $-0.0911(5)$ & $0.49233(12)$ & $0.0637(9)$ & \\
\hline $\mathrm{H} 7$ & 0.3350 & -0.2480 & 0.4802 & $0.076^{*}$ & \\
\hline $\mathrm{C} 3$ & $0.4257(2)$ & $0.4676(7)$ & $0.85504(15)$ & $0.0804(11)$ & \\
\hline H3AA & 0.4303 & 0.5434 & 0.8928 & $0.097^{*}$ & $0.865(8)$ \\
\hline $\mathrm{H} 3 \mathrm{AB}$ & 0.4325 & 0.2983 & 0.8623 & $0.097^{*}$ & $0.865(8)$ \\
\hline H3BC & 0.4217 & 0.3299 & 0.8784 & $0.097^{*}$ & $0.135(8)$ \\
\hline H3BD & 0.4525 & 0.4145 & 0.8292 & $0.097^{*}$ & $0.135(8)$ \\
\hline $\mathrm{C} 4 \mathrm{~A}$ & $0.4845(3)$ & $0.5576(11)$ & $0.8329(2)$ & 0.1011 (19) & $0.865(8)$ \\
\hline H4AA & 0.5301 & 0.5092 & 0.8608 & $0.121^{*}$ & $0.865(8)$ \\
\hline $\mathrm{H} 4 \mathrm{AB}$ & 0.4800 & 0.4808 & 0.7952 & $0.121^{*}$ & $0.865(8)$ \\
\hline $\mathrm{C} 4 \mathrm{~B}$ & $0.473(2)$ & $0.624(7)$ & $0.8964(16)$ & $0.114(9)$ & $0.135(8)$ \\
\hline H4BA & 0.4527 & 0.6638 & 0.9274 & $0.136^{*}$ & $0.135(8)$ \\
\hline H4BB & 0.5181 & 0.5409 & 0.9150 & $0.136^{*}$ & $0.135(8)$ \\
\hline $\mathrm{C} 5 \mathrm{~A}$ & $0.4863(4)$ & $0.8168(15)$ & $0.8244(5)$ & $0.143(3)$ & $0.865(8)$ \\
\hline H5AA & 0.4440 & 0.8653 & 0.7934 & $0.214^{*}$ & $0.865(8)$ \\
\hline
\end{tabular}
matrix. The cell esds are taken into account individually in the estimation of esds in distances, angles and torsion angles; correlations between esds in cell parameters are only used when they are defined by crystal symmetry. An approximate (isotropic) treatment of cell esds is used for estimating esds involving l.s. planes.

Fractional atomic coordinates and isotropic or equivalent isotropic displacement parameters $\left(\AA^{2}\right)$ 
supporting information

\begin{tabular}{llllll} 
H5AB & 0.5280 & 0.8578 & 0.8135 & $0.214^{*}$ & $0.865(8)$ \\
H5AC & 0.4881 & 0.8961 & 0.8607 & $0.214^{*}$ & $0.865(8)$ \\
C5B & $0.488(4)$ & $0.829(11)$ & $0.872(3)$ & $0.166(18)$ & $0.135(8)$ \\
H5BA & 0.4471 & 0.8746 & 0.8392 & $0.249^{*}$ & $0.135(8)$ \\
H5BB & 0.5285 & 0.8054 & 0.8581 & $0.249^{*}$ & $0.135(8)$ \\
H5BC & 0.4988 & 0.9530 & 0.9014 & $0.249^{*}$ & $0.135(8)$ \\
\hline
\end{tabular}

Atomic displacement parameters $\left(\AA^{2}\right)$

\begin{tabular}{lllllll}
\hline & $U^{11}$ & $U^{22}$ & $U^{33}$ & $U^{12}$ & $U^{13}$ & $U^{23}$ \\
\hline O2 & $0.0956(16)$ & $0.0514(12)$ & $0.0351(10)$ & $-0.0135(11)$ & $0.0289(9)$ & $-0.0092(8)$ \\
O4 & $0.1220(19)$ & $0.0344(10)$ & $0.0397(10)$ & $-0.0056(10)$ & $0.0336(10)$ & $0.0026(7)$ \\
O6 & $0.1231(19)$ & $0.0385(11)$ & $0.0417(11)$ & $-0.0051(11)$ & $0.0364(12)$ & $-0.0074(8)$ \\
O5 & $0.1054(17)$ & $0.0600(12)$ & $0.0355(10)$ & $0.0015(11)$ & $0.0350(10)$ & $-0.0014(8)$ \\
O3 & $0.139(2)$ & $0.0517(12)$ & $0.0381(11)$ & $-0.0037(12)$ & $0.0405(12)$ & $-0.0057(8)$ \\
O1 & $0.129(2)$ & $0.0787(16)$ & $0.0470(12)$ & $-0.0372(14)$ & $0.0501(13)$ & $-0.0171(10)$ \\
N1 & $0.0863(18)$ & $0.0445(13)$ & $0.0319(11)$ & $0.0082(11)$ & $0.0240(11)$ & $-0.0036(9)$ \\
C9 & $0.0698(19)$ & $0.0395(14)$ & $0.0354(14)$ & $0.0031(12)$ & $0.0208(12)$ & $0.0009(10)$ \\
C1 & $0.0698(19)$ & $0.0502(17)$ & $0.0322(13)$ & $-0.0032(14)$ & $0.0221(12)$ & $-0.0026(11)$ \\
C6 & $0.087(2)$ & $0.0372(14)$ & $0.0364(14)$ & $-0.0011(13)$ & $0.0279(13)$ & $-0.0007(11)$ \\
C2 & $0.072(2)$ & $0.0471(15)$ & $0.0380(14)$ & $-0.0066(13)$ & $0.0210(13)$ & $-0.0077(11)$ \\
C8 & $0.111(3)$ & $0.0333(14)$ & $0.0418(15)$ & $0.0039(15)$ & $0.0321(15)$ & $0.0065(11)$ \\
C7 & $0.124(3)$ & $0.0296(13)$ & $0.0429(15)$ & $0.0042(15)$ & $0.0347(16)$ & $-0.0041(11)$ \\
C3 & $0.082(3)$ & $0.088(3)$ & $0.065(2)$ & $0.002(2)$ & $0.0144(19)$ & $-0.0186(18)$ \\
C4A & $0.072(3)$ & $0.129(5)$ & $0.096(3)$ & $-0.002(3)$ & $0.019(3)$ & $-0.028(3)$ \\
C4B & $0.114(16)$ & $0.106(16)$ & $0.104(16)$ & $-0.005(15)$ & $0.012(14)$ & $-0.044(14)$ \\
C5A & $0.112(5)$ & $0.122(6)$ & $0.195(9)$ & $-0.031(4)$ & $0.050(6)$ & $-0.010(6)$ \\
C5B & $0.15(3)$ & $0.15(3)$ & $0.17(3)$ & $-0.03(3)$ & $0.01(3)$ & $-0.05(3)$ \\
& & & & & &
\end{tabular}

Geometric parameters $\left(A,{ }^{\circ}\right)$

\begin{tabular}{llll}
\hline $\mathrm{O} 2-\mathrm{C} 1$ & $1.202(3)$ & $\mathrm{C} 7-\mathrm{H} 7$ & 0.9300 \\
$\mathrm{O} 4-\mathrm{C} 6$ & $1.274(3)$ & $\mathrm{C} 3-\mathrm{H} 3 \mathrm{AA}$ & 0.9700 \\
$\mathrm{O} 6-\mathrm{H} 6$ & 0.8200 & $\mathrm{C} 3-\mathrm{H} 3 \mathrm{AB}$ & 0.9700 \\
$\mathrm{O} 6-\mathrm{C} 9$ & $1.275(3)$ & $\mathrm{C} 3-\mathrm{H} 3 \mathrm{BC}$ & 0.9700 \\
$\mathrm{O} 5-\mathrm{C} 9$ & $1.231(3)$ & $\mathrm{C} 3-\mathrm{H} 3 \mathrm{BD}$ & 0.9700 \\
$\mathrm{O} 3-\mathrm{C} 6$ & $1.226(3)$ & $\mathrm{C} 3-\mathrm{C} 4 \mathrm{~A}$ & $1.498(6)$ \\
$\mathrm{O} 1-\mathrm{H} 1$ & 0.8200 & $\mathrm{C} 3-\mathrm{C} 4 \mathrm{~B}$ & $1.43(3)$ \\
$\mathrm{O} 1-\mathrm{C} 1$ & $1.308(3)$ & $\mathrm{C} 4 \mathrm{~A}-\mathrm{H} 4 \mathrm{AA}$ & 0.9700 \\
$\mathrm{~N} 1-\mathrm{H} 1 \mathrm{~A}$ & 0.8900 & $\mathrm{C} 4 \mathrm{~A}-\mathrm{H} 4 \mathrm{AB}$ & 0.9700 \\
$\mathrm{~N} 1-\mathrm{H} 1 \mathrm{~B}$ & 0.8900 & $\mathrm{C} 4 \mathrm{~A}-\mathrm{C} 5 \mathrm{~A}$ & $1.474(9)$ \\
$\mathrm{N} 1-\mathrm{H} 1 \mathrm{C}$ & 0.8900 & $\mathrm{C} 4 \mathrm{~B}-\mathrm{H} 4 \mathrm{BA}$ & 0.9700 \\
$\mathrm{~N} 1-\mathrm{C} 2$ & $1.482(4)$ & $\mathrm{C} 4 \mathrm{~B}-\mathrm{H} 4 \mathrm{BB}$ & 0.9700 \\
$\mathrm{C} 9-\mathrm{C} 8$ & $1.469(4)$ & $\mathrm{C} 4 \mathrm{~B}-\mathrm{C} 5 \mathrm{~B}$ & $1.36(7)$ \\
$\mathrm{C} 1-\mathrm{C} 2$ & $1.507(4)$ & $\mathrm{C} 5 \mathrm{~A}-\mathrm{H} 5 \mathrm{AA}$ & 0.9600 \\
$\mathrm{C} 6-\mathrm{C} 7$ & $1.490(4)$ & $\mathrm{C} 5 \mathrm{~A}-\mathrm{H} 5 \mathrm{AB}$ & 0.9600 \\
$\mathrm{C} 2-\mathrm{H} 2$ & 0.9800 & $\mathrm{C} 5 \mathrm{~A}-\mathrm{H} 5 \mathrm{AC}$ & 0.9600 \\
$\mathrm{C} 2-\mathrm{C} 3$ & $1.517(5)$ & $\mathrm{C} 5 \mathrm{~B}-\mathrm{H} 5 \mathrm{BA}$ & 0.9600
\end{tabular}




\begin{tabular}{|c|c|c|c|}
\hline $\mathrm{C} 8-\mathrm{H} 8$ & 0.9300 & $\mathrm{C} 5 \mathrm{~B}-\mathrm{H} 5 \mathrm{BB}$ & 0.9600 \\
\hline $\mathrm{C} 8-\mathrm{C} 7$ & $1.329(4)$ & $\mathrm{C} 5 \mathrm{~B}-\mathrm{H} 5 \mathrm{BC}$ & 0.9600 \\
\hline $\mathrm{C} 9-\mathrm{O} 6-\mathrm{H} 6$ & 109.5 & $\mathrm{H} 3 \mathrm{AA}-\mathrm{C} 3-\mathrm{H} 3 \mathrm{AB}$ & 107.5 \\
\hline $\mathrm{C} 1-\mathrm{O} 1-\mathrm{H} 1$ & 109.5 & $\mathrm{H} 3 \mathrm{BC}-\mathrm{C} 3-\mathrm{H} 3 \mathrm{BD}$ & 105.7 \\
\hline $\mathrm{H} 1 \mathrm{~A}-\mathrm{N} 1-\mathrm{H} 1 \mathrm{~B}$ & 109.5 & $\mathrm{C} 4 \mathrm{~A}-\mathrm{C} 3-\mathrm{C} 2$ & $115.2(3)$ \\
\hline $\mathrm{H} 1 \mathrm{~A}-\mathrm{N} 1-\mathrm{H} 1 \mathrm{C}$ & 109.5 & $\mathrm{C} 4 \mathrm{~A}-\mathrm{C} 3-\mathrm{H} 3 \mathrm{AA}$ & 108.5 \\
\hline $\mathrm{H} 1 \mathrm{~B}-\mathrm{N} 1-\mathrm{H} 1 \mathrm{C}$ & 109.5 & $\mathrm{C} 4 \mathrm{~A}-\mathrm{C} 3-\mathrm{H} 3 \mathrm{AB}$ & 108.5 \\
\hline $\mathrm{C} 2-\mathrm{N} 1-\mathrm{H} 1 \mathrm{~A}$ & 109.5 & $\mathrm{C} 4 \mathrm{~B}-\mathrm{C} 3-\mathrm{C} 2$ & $130.3(16)$ \\
\hline $\mathrm{C} 2-\mathrm{N} 1-\mathrm{H} 1 \mathrm{~B}$ & 109.5 & $\mathrm{C} 4 \mathrm{~B}-\mathrm{C} 3-\mathrm{H} 3 \mathrm{BC}$ & 104.7 \\
\hline $\mathrm{C} 2-\mathrm{N} 1-\mathrm{H} 1 \mathrm{C}$ & 109.5 & $\mathrm{C} 4 \mathrm{~B}-\mathrm{C} 3-\mathrm{H} 3 \mathrm{BD}$ & 104.7 \\
\hline $\mathrm{O} 6-\mathrm{C} 9-\mathrm{C} 8$ & $120.8(2)$ & $\mathrm{C} 3-\mathrm{C} 4 \mathrm{~A}-\mathrm{H} 4 \mathrm{AA}$ & 108.3 \\
\hline $\mathrm{O} 5-\mathrm{C} 9-\mathrm{O} 6$ & $121.7(2)$ & $\mathrm{C} 3-\mathrm{C} 4 \mathrm{~A}-\mathrm{H} 4 \mathrm{AB}$ & 108.3 \\
\hline $\mathrm{O} 5-\mathrm{C} 9-\mathrm{C} 8$ & $117.6(2)$ & $\mathrm{H} 4 \mathrm{AA}-\mathrm{C} 4 \mathrm{~A}-\mathrm{H} 4 \mathrm{AB}$ & 107.4 \\
\hline $\mathrm{O} 2-\mathrm{C} 1-\mathrm{O} 1$ & $125.0(2)$ & $\mathrm{C} 5 \mathrm{~A}-\mathrm{C} 4 \mathrm{~A}-\mathrm{C} 3$ & $115.9(5)$ \\
\hline $\mathrm{O} 2-\mathrm{C} 1-\mathrm{C} 2$ & $122.4(2)$ & $\mathrm{C} 5 \mathrm{~A}-\mathrm{C} 4 \mathrm{~A}-\mathrm{H} 4 \mathrm{AA}$ & 108.3 \\
\hline $\mathrm{O} 1-\mathrm{C} 1-\mathrm{C} 2$ & $112.6(2)$ & $\mathrm{C} 5 \mathrm{~A}-\mathrm{C} 4 \mathrm{~A}-\mathrm{H} 4 \mathrm{AB}$ & 108.3 \\
\hline $\mathrm{O} 4-\mathrm{C} 6-\mathrm{C} 7$ & $119.1(2)$ & $\mathrm{C} 3-\mathrm{C} 4 \mathrm{~B}-\mathrm{H} 4 \mathrm{BA}$ & 108.7 \\
\hline $\mathrm{O} 3-\mathrm{C} 6-\mathrm{O} 4$ & $122.4(2)$ & $\mathrm{C} 3-\mathrm{C} 4 \mathrm{~B}-\mathrm{H} 4 \mathrm{BB}$ & 108.7 \\
\hline $\mathrm{O} 3-\mathrm{C} 6-\mathrm{C} 7$ & $118.5(2)$ & $\mathrm{H} 4 \mathrm{BA}-\mathrm{C} 4 \mathrm{~B}-\mathrm{H} 4 \mathrm{BB}$ & 107.6 \\
\hline $\mathrm{N} 1-\mathrm{C} 2-\mathrm{C} 1$ & $107.4(2)$ & $\mathrm{C} 5 \mathrm{~B}-\mathrm{C} 4 \mathrm{~B}-\mathrm{C} 3$ & $114(3)$ \\
\hline $\mathrm{N} 1-\mathrm{C} 2-\mathrm{H} 2$ & 109.3 & $\mathrm{C} 5 \mathrm{~B}-\mathrm{C} 4 \mathrm{~B}-\mathrm{H} 4 \mathrm{BA}$ & 108.7 \\
\hline $\mathrm{N} 1-\mathrm{C} 2-\mathrm{C} 3$ & $108.9(2)$ & $\mathrm{C} 5 \mathrm{~B}-\mathrm{C} 4 \mathrm{~B}-\mathrm{H} 4 \mathrm{BB}$ & 108.7 \\
\hline $\mathrm{C} 1-\mathrm{C} 2-\mathrm{H} 2$ & 109.3 & $\mathrm{C} 4 \mathrm{~A}-\mathrm{C} 5 \mathrm{~A}-\mathrm{H} 5 \mathrm{AA}$ & 109.5 \\
\hline $\mathrm{C} 1-\mathrm{C} 2-\mathrm{C} 3$ & $112.7(3)$ & $\mathrm{C} 4 \mathrm{~A}-\mathrm{C} 5 \mathrm{~A}-\mathrm{H} 5 \mathrm{AB}$ & 109.5 \\
\hline $\mathrm{C} 3-\mathrm{C} 2-\mathrm{H} 2$ & 109.3 & $\mathrm{C} 4 \mathrm{~A}-\mathrm{C} 5 \mathrm{~A}-\mathrm{H} 5 \mathrm{AC}$ & 109.5 \\
\hline $\mathrm{C} 9-\mathrm{C} 8-\mathrm{H} 8$ & 114.7 & $\mathrm{H} 5 \mathrm{AA}-\mathrm{C} 5 \mathrm{~A}-\mathrm{H} 5 \mathrm{AB}$ & 109.5 \\
\hline $\mathrm{C} 7-\mathrm{C} 8-\mathrm{C} 9$ & $130.6(2)$ & $\mathrm{H} 5 \mathrm{AA}-\mathrm{C} 5 \mathrm{~A}-\mathrm{H} 5 \mathrm{AC}$ & 109.5 \\
\hline $\mathrm{C} 7-\mathrm{C} 8-\mathrm{H} 8$ & 114.7 & $\mathrm{H} 5 \mathrm{AB}-\mathrm{C} 5 \mathrm{~A}-\mathrm{H} 5 \mathrm{AC}$ & 109.5 \\
\hline $\mathrm{C} 6-\mathrm{C} 7-\mathrm{H} 7$ & 114.6 & $\mathrm{C} 4 \mathrm{~B}-\mathrm{C} 5 \mathrm{~B}-\mathrm{H} 5 \mathrm{BA}$ & 109.5 \\
\hline $\mathrm{C} 8-\mathrm{C} 7-\mathrm{C} 6$ & $130.8(2)$ & $\mathrm{C} 4 \mathrm{~B}-\mathrm{C} 5 \mathrm{~B}-\mathrm{H} 5 \mathrm{BB}$ & 109.5 \\
\hline $\mathrm{C} 8-\mathrm{C} 7-\mathrm{H} 7$ & 114.6 & $\mathrm{C} 4 \mathrm{~B}-\mathrm{C} 5 \mathrm{~B}-\mathrm{H} 5 \mathrm{BC}$ & 109.5 \\
\hline $\mathrm{C} 2-\mathrm{C} 3-\mathrm{H} 3 \mathrm{AA}$ & 108.5 & $\mathrm{H} 5 \mathrm{BA}-\mathrm{C} 5 \mathrm{~B}-\mathrm{H} 5 \mathrm{BB}$ & 109.5 \\
\hline $\mathrm{C} 2-\mathrm{C} 3-\mathrm{H} 3 \mathrm{AB}$ & 108.5 & $\mathrm{H} 5 \mathrm{BA}-\mathrm{C} 5 \mathrm{~B}-\mathrm{H} 5 \mathrm{BC}$ & 109.5 \\
\hline $\mathrm{C} 2-\mathrm{C} 3-\mathrm{H} 3 \mathrm{BC}$ & 104.7 & $\mathrm{H} 5 \mathrm{BB}-\mathrm{C} 5 \mathrm{~B}-\mathrm{H} 5 \mathrm{BC}$ & 109.5 \\
\hline $\mathrm{C} 2-\mathrm{C} 3-\mathrm{H} 3 \mathrm{BD}$ & 104.7 & & \\
\hline $\mathrm{O} 2-\mathrm{C} 1-\mathrm{C} 2-\mathrm{N} 1$ & $-26.0(4)$ & $\mathrm{N} 1-\mathrm{C} 2-\mathrm{C} 3-\mathrm{C} 4 \mathrm{~A}$ & $-170.8(3)$ \\
\hline $\mathrm{O} 2-\mathrm{C} 1-\mathrm{C} 2-\mathrm{C} 3$ & 93.9 (4) & $\mathrm{N} 1-\mathrm{C} 2-\mathrm{C} 3-\mathrm{C} 4 \mathrm{~B}$ & $-90(2)$ \\
\hline $\mathrm{O} 4-\mathrm{C} 6-\mathrm{C} 7-\mathrm{C} 8$ & $5.0(6)$ & $\mathrm{C} 9-\mathrm{C} 8-\mathrm{C} 7-\mathrm{C} 6$ & $-0.4(7)$ \\
\hline $\mathrm{O} 6-\mathrm{C} 9-\mathrm{C} 8-\mathrm{C} 7$ & $-5.4(6)$ & $\mathrm{C} 1-\mathrm{C} 2-\mathrm{C} 3-\mathrm{C} 4 \mathrm{~A}$ & $70.1(4)$ \\
\hline $\mathrm{O} 5-\mathrm{C} 9-\mathrm{C} 8-\mathrm{C} 7$ & $175.1(4)$ & $\mathrm{C} 1-\mathrm{C} 2-\mathrm{C} 3-\mathrm{C} 4 \mathrm{~B}$ & $151(2)$ \\
\hline $\mathrm{O} 3-\mathrm{C} 6-\mathrm{C} 7-\mathrm{C} 8$ & $-174.1(4)$ & $\mathrm{C} 2-\mathrm{C} 3-\mathrm{C} 4 \mathrm{~A}-\mathrm{C} 5 \mathrm{~A}$ & $63.3(7)$ \\
\hline $\mathrm{O} 1-\mathrm{C} 1-\mathrm{C} 2-\mathrm{N} 1$ & $154.9(3)$ & $\mathrm{C} 2-\mathrm{C} 3-\mathrm{C} 4 \mathrm{~B}-\mathrm{C} 5 \mathrm{~B}$ & $-57(5)$ \\
\hline $\mathrm{O} 1-\mathrm{C} 1-\mathrm{C} 2-\mathrm{C} 3$ & $-85.1(3)$ & & \\
\hline
\end{tabular}


Hydrogen-bond geometry $\left(\AA,{ }^{\circ}\right)$

\begin{tabular}{lllll}
\hline$D-\mathrm{H} \cdots A$ & $D-\mathrm{H}$ & $\mathrm{H} \cdots A$ & $D \cdots A$ & $D-\mathrm{H} \cdots A$ \\
\hline $\mathrm{O} 6-\mathrm{H} 6 \cdots \mathrm{O} 4$ & 0.82 & 1.60 & $2.421(2)$ & 178 \\
$\mathrm{O} 1-\mathrm{H} 1 \cdots \mathrm{O} 5$ & 0.82 & 1.80 & $2.612(3)$ & 171 \\
$\mathrm{~N} 1-\mathrm{H} 1 A \cdots \mathrm{O} 2^{\mathrm{i}}$ & 0.89 & 2.11 & $2.864(3)$ & 142 \\
$\mathrm{~N} 1-\mathrm{H} 1 B \cdots \mathrm{O} 44^{\mathrm{ii}}$ & 0.89 & 2.01 & $2.898(3)$ & 172 \\
$\mathrm{~N} 1-\mathrm{H} 1 C \cdots \mathrm{O} 3^{\text {iii }}$ & 0.89 & 1.97 & $2.850(3)$ & 168
\end{tabular}

Symmetry codes: (i) $-x+1 / 2, y+1 / 2,-z+3 / 2$; (ii) $x,-y+1, z+1 / 2$; (iii) $x,-y, z+1 / 2$.

(2dl_nv_mal) $D L$-Norvalinium hydrogen maleate-DL-norvaline (1/1)

Crystal data

$\mathrm{C}_{5} \mathrm{H}_{12} \mathrm{NO}_{2}{ }^{+} \cdot \mathrm{C}_{4} \mathrm{H}_{3} \mathrm{O}_{4}{ }^{-} \cdot \mathrm{C}_{5} \mathrm{H}_{11} \mathrm{NO}_{2}$

$M_{r}=350.37$

Orthorhombic, Pnma

$a=8.8572(4) \AA$

$b=27.3614$ (11) $\AA$

$c=7.8306(4) \AA$

$V=1897.71(15) \AA^{3}$

$Z=4$

$F(000)=752$

\section{Data collection}

Agilent Xcalibur Ruby Gemini ultra diffractometer

Radiation source: fine-focus sealed X-ray tube, Enhance (Mo) X-ray Source

Graphite monochromator

Detector resolution: 10.3457 pixels $\mathrm{mm}^{-1}$

$\omega$ scans

Absorption correction: multi-scan

(CrysAlis PRO; Agilent, 2014)

\section{Refinement}

Refinement on $F^{2}$

Least-squares matrix: full

$R\left[F^{2}>2 \sigma\left(F^{2}\right)\right]=0.079$

$w R\left(F^{2}\right)=0.146$

$S=1.14$

1975 reflections

216 parameters

298 restraints

Primary atom site location: dual
$D_{\mathrm{x}}=1.226 \mathrm{Mg} \mathrm{m}^{-3}$

Mo $K \alpha$ radiation, $\lambda=0.71073 \AA$

Cell parameters from 6447 reflections

$\theta=2.3-27.7^{\circ}$

$\mu=0.10 \mathrm{~mm}^{-1}$

$T=293 \mathrm{~K}$

Block, clear light colourless

$0.5 \times 0.25 \times 0.2 \mathrm{~mm}$

$T_{\min }=0.948, T_{\max }=1.000$

21923 measured reflections

1975 independent reflections

1731 reflections with $I>2 \sigma(I)$

$R_{\text {int }}=0.053$

$\theta_{\max }=26.4^{\circ}, \theta_{\min }=3.0^{\circ}$

$h=-11 \rightarrow 11$

$k=-34 \rightarrow 34$

$l=-9 \rightarrow 9$

Hydrogen site location: mixed

$\mathrm{H}$ atoms treated by a mixture of independent and constrained refinement

$w=1 /\left[\sigma^{2}\left(F_{\mathrm{o}}^{2}\right)+2.5627 P\right]$

where $P=\left(F_{\mathrm{o}}^{2}+2 F_{\mathrm{c}}^{2}\right) / 3$

$(\Delta / \sigma)_{\max }<0.001$

$\Delta \rho_{\max }=0.15$ e $\AA^{-3}$

$\Delta \rho_{\min }=-0.20$ e $\AA^{-3}$

Special details

Geometry. All esds (except the esd in the dihedral angle between two 1.s. planes) are estimated using the full covariance matrix. The cell esds are taken into account individually in the estimation of esds in distances, angles and torsion angles; correlations between esds in cell parameters are only used when they are defined by crystal symmetry. An approximate (isotropic) treatment of cell esds is used for estimating esds involving 1.s. planes. 
Fractional atomic coordinates and isotropic or equivalent isotropic displacement parameters $\left(\AA^{2}\right)$

\begin{tabular}{|c|c|c|c|c|c|}
\hline & $x$ & $y$ & $z$ & $U_{\text {iso }} * / U_{\text {eq }}$ & Occ. $(<1)$ \\
\hline $\mathrm{O} 1$ & $0.3996(7)$ & 0.5283 & $0.4353(8)$ & $0.0588(14)$ & $0.733(5)$ \\
\hline $\mathrm{O} 2$ & $0.2253(12)$ & $0.4842(4)$ & $0.5382(11)$ & 0.0673 (19) & $0.733(5)$ \\
\hline N1 & $0.1895(3)$ & $0.58452(10)$ & $0.2864(4)$ & $0.0436(9)$ & $0.733(5)$ \\
\hline H1A & 0.209236 & 0.566396 & 0.194754 & $0.052 *$ & $0.733(5)$ \\
\hline H1B & 0.271973 & 0.601006 & 0.316357 & $0.052 *$ & $0.733(5)$ \\
\hline $\mathrm{H} 1 \mathrm{C}$ & 0.115546 & 0.605455 & 0.262507 & $0.052 *$ & $0.733(5)$ \\
\hline $\mathrm{C} 1$ & $0.2668(10)$ & $0.5162(3)$ & $0.486(2)$ & $0.053(2)$ & $0.733(5)$ \\
\hline C6 & $0.4597(4)$ & $0.69058(10)$ & $0.2591(5)$ & $0.0667(9)$ & \\
\hline $\mathrm{C} 3$ & $0.0925(9)$ & $0.5831(2)$ & $0.5848(10)$ & $0.0563(15)$ & $0.733(5)$ \\
\hline $\mathrm{H} 3 \mathrm{~A}$ & 0.015017 & 0.605821 & 0.547903 & $0.068 *$ & $0.733(5)$ \\
\hline H3B & 0.047697 & 0.561615 & 0.669252 & $0.068^{*}$ & $0.733(5)$ \\
\hline $\mathrm{C} 2$ & $0.1420(5)$ & $0.55218(16)$ & $0.4302(6)$ & $0.0450(10)$ & $0.733(5)$ \\
\hline $\mathrm{H} 2$ & 0.054865 & 0.533011 & 0.392004 & $0.054 *$ & $0.733(5)$ \\
\hline O4 & $0.4852(12)$ & $0.70580(16)$ & $0.1052(7)$ & $0.082(3)$ & $0.532(13)$ \\
\hline $\mathrm{C} 4$ & $0.2156(11)$ & $0.6112(4)$ & $0.6672(11)$ & $0.078(2)$ & $0.733(5)$ \\
\hline $\mathrm{H} 4 \mathrm{~A}$ & 0.258051 & 0.633807 & 0.584784 & $0.093 *$ & $0.733(5)$ \\
\hline H4B & 0.295023 & 0.588785 & 0.701321 & $0.093 *$ & $0.733(5)$ \\
\hline $\mathrm{C} 7$ & $0.4209(11)$ & $0.7257(3)$ & $0.3969(11)$ & $0.055(2)$ & $0.532(13)$ \\
\hline $\mathrm{H} 7$ & 0.391943 & 0.711475 & 0.499571 & $0.066^{*}$ & $0.532(13)$ \\
\hline O4B & $0.5932(11)$ & $0.70603(18)$ & 0.1975 (19) & $0.112(5)$ & $0.468(13)$ \\
\hline N1B & $0.0750(11)$ & $0.5607(3)$ & $0.3297(13)$ & $0.054(3)$ & $0.267(5)$ \\
\hline H1BA & 0.116614 & 0.543114 & 0.246574 & $0.065^{*}$ & $0.267(5)$ \\
\hline H1BB & 0.034246 & 0.587671 & 0.285670 & $0.065^{*}$ & $0.267(5)$ \\
\hline H1BC & 0.003694 & 0.543223 & 0.381236 & $0.065^{*}$ & $0.267(5)$ \\
\hline O1B & $0.425(2)$ & $0.5365(8)$ & $0.503(2)$ & $0.067(5)$ & $0.267(5)$ \\
\hline $\mathrm{O} 2 \mathrm{~B}$ & $0.229(4)$ & $0.4803(10)$ & 0.593 & $0.066(5)$ & $0.267(5)$ \\
\hline $\mathrm{C} 2 \mathrm{~B}$ & $0.1906(15)$ & $0.5742(4)$ & 0.4535 (19) & $0.054(3)$ & $0.267(5)$ \\
\hline $\mathrm{H} 2 \mathrm{~B}$ & 0.259337 & 0.597557 & 0.399015 & $0.064 *$ & $0.267(5)$ \\
\hline $\mathrm{C} 7 \mathrm{~B}$ & $0.3551(12)$ & $0.7257(3)$ & $0.3272(18)$ & $0.068(3)$ & $0.468(13)$ \\
\hline H7B & 0.271968 & 0.711838 & 0.381295 & $0.082 *$ & $0.468(13)$ \\
\hline C1B & $0.271(3)$ & $0.5271(8)$ & $0.473(7)$ & $0.049(4)$ & $0.267(5)$ \\
\hline $\mathrm{C} 3 \mathrm{~B}$ & $0.117(4)$ & $0.5995(9)$ & $0.605(4)$ & $0.086(6)$ & $0.267(5)$ \\
\hline H3BA & 0.052294 & 0.625599 & 0.563819 & $0.103 *$ & $0.267(5)$ \\
\hline H3BB & 0.053207 & 0.576156 & 0.664850 & $0.103 *$ & $0.267(5)$ \\
\hline $\mathrm{C} 4 \mathrm{~B}$ & $0.223(4)$ & 0.6193 (12) & $0.723(4)$ & $0.107(7)$ & $0.267(5)$ \\
\hline H4BA & 0.240324 & 0.596531 & 0.815453 & $0.129 *$ & $0.267(5)$ \\
\hline H4BB & 0.318602 & 0.625157 & 0.665381 & $0.129 *$ & $0.267(5)$ \\
\hline $\mathrm{O} 3$ & $0.453(5)$ & $0.6486(10)$ & $0.284(6)$ & $0.073(7)$ & $0.532(13)$ \\
\hline O3B & $0.440(5)$ & $0.6447(12)$ & $0.290(6)$ & $0.063(5)$ & $0.468(13)$ \\
\hline $\mathrm{C} 5$ & $0.1602(13)$ & $0.6408(3)$ & $0.8296(14)$ & $0.096(3)$ & $0.733(5)$ \\
\hline $\mathrm{H} 5 \mathrm{~A}$ & 0.089387 & 0.665441 & 0.794706 & $0.145^{*}$ & $0.733(5)$ \\
\hline H5B & 0.245280 & 0.656078 & 0.883680 & $0.145^{*}$ & $0.733(5)$ \\
\hline $\mathrm{H} 5 \mathrm{C}$ & 0.112409 & 0.618901 & 0.908534 & $0.145^{*}$ & $0.733(5)$ \\
\hline C5B & $0.170(5)$ & $0.6600(9)$ & $0.782(5)$ & $0.129(11)$ & $0.267(5)$ \\
\hline H5BA & 0.103300 & 0.674308 & 0.698621 & $0.193 *$ & $0.267(5)$ \\
\hline
\end{tabular}




\begin{tabular}{llllll} 
H5BB & 0.251346 & 0.682068 & 0.804935 & $0.193^{*}$ & $0.267(5)$ \\
H5BC & 0.114773 & 0.653731 & 0.885012 & $0.193^{*}$ & $0.267(5)$ \\
H1 & 0.500000 & 0.500000 & 0.500000 & $0.193^{*}$ & \\
H4 & $0.483(9)$ & 0.750000 & $0.115(11)$ & $0.193^{*}$ & \\
\hline
\end{tabular}

Atomic displacement parameters $\left(\AA^{2}\right)$

\begin{tabular}{lllllll}
\hline & $U^{11}$ & $U^{22}$ & $U^{33}$ & $U^{12}$ & $U^{13}$ & $U^{23}$ \\
\hline O1 & $0.044(3)$ & $0.052(3)$ & $0.080(4)$ & $0.016(2)$ & $0.004(2)$ & $0.021(3)$ \\
O2 & $0.058(2)$ & $0.061(4)$ & $0.083(6)$ & $0.005(2)$ & $0.002(4)$ & $0.030(4)$ \\
$\mathrm{N} 1$ & $0.0397(17)$ & $0.0352(15)$ & $0.056(2)$ & $0.0090(13)$ & $-0.0013(15)$ & $0.0050(14)$ \\
C1 & $0.045(3)$ & $0.051(4)$ & $0.061(5)$ & $0.023(3)$ & $0.001(3)$ & $0.019(5)$ \\
C6 & $0.064(2)$ & $0.0354(15)$ & $0.101(3)$ & $0.0003(13)$ & $0.0253(19)$ & $-0.0043(17)$ \\
C3 & $0.048(3)$ & $0.052(3)$ & $0.069(4)$ & $0.018(2)$ & $0.009(3)$ & $0.006(3)$ \\
C2 & $0.040(2)$ & $0.034(2)$ & $0.061(3)$ & $0.0051(18)$ & $0.001(2)$ & $0.008(2)$ \\
O4 & $0.115(7)$ & $0.047(2)$ & $0.084(3)$ & $0.000(3)$ & $0.028(4)$ & $-0.011(2)$ \\
C4 & $0.072(4)$ & $0.080(4)$ & $0.081(5)$ & $0.010(3)$ & $0.014(4)$ & $-0.023(4)$ \\
C7 & $0.066(5)$ & $0.035(3)$ & $0.065(4)$ & $-0.001(3)$ & $0.007(4)$ & $0.003(3)$ \\
O4B & $0.070(5)$ & $0.043(3)$ & $0.223(12)$ & $0.004(3)$ & $0.081(7)$ & $0.000(4)$ \\
N1B & $0.050(6)$ & $0.041(5)$ & $0.070(6)$ & $0.009(4)$ & $-0.002(5)$ & $0.010(4)$ \\
O1B & $0.044(6)$ & $0.057(7)$ & $0.101(14)$ & $0.013(5)$ & $0.003(7)$ & $0.017(9)$ \\
O2B & $0.074(7)$ & $0.059(6)$ & $0.064(11)$ & $0.029(5)$ & $0.017(8)$ & $0.050(7)$ \\
C2B & $0.050(6)$ & $0.029(5)$ & $0.083(8)$ & $0.012(5)$ & $-0.006(6)$ & $0.008(5)$ \\
C7B & $0.048(5)$ & $0.038(3)$ & $0.119(9)$ & $0.000(4)$ & $0.027(5)$ & $-0.002(5)$ \\
C1B & $0.053(7)$ & $0.035(8)$ & $0.059(10)$ & $0.006(6)$ & $0.014(6)$ & $0.026(7)$ \\
C3B & $0.084(13)$ & $0.090(14)$ & $0.083(10)$ & $0.037(11)$ & $-0.002(9)$ & $-0.005(9)$ \\
C4B & $0.127(15)$ & $0.103(14)$ & $0.092(15)$ & $0.041(12)$ & $-0.025(13)$ & $-0.013(10)$ \\
O3 & $0.071(14)$ & $0.023(4)$ & $0.124(11)$ & $0.004(5)$ & $0.026(9)$ & $0.005(5)$ \\
O3B & $0.050(6)$ & $0.032(6)$ & $0.108(12)$ & $0.002(6)$ & $0.019(7)$ & $-0.007(7)$ \\
C5 & $0.098(5)$ & $0.094(7)$ & $0.097(6)$ & $0.020(5)$ & $0.004(4)$ & $-0.023(5)$ \\
C5B & $0.20(3)$ & $0.071(14)$ & $0.12(2)$ & $0.029(16)$ & $0.020(18)$ & $0.002(12)$ \\
& & & & & & \\
\hline & & & & & &
\end{tabular}

Geometric parameters $\left(\hat{A},{ }^{\circ}\right)$

\begin{tabular}{llll}
\hline $\mathrm{O} 1-\mathrm{C} 1$ & $1.286(11)$ & $\mathrm{N} 1 \mathrm{~B}-\mathrm{H} 1 \mathrm{BA}$ & 0.8900 \\
$\mathrm{O} 1-\mathrm{H} 1$ & $1.284(6)$ & $\mathrm{N} 1 \mathrm{~B}-\mathrm{H} 1 \mathrm{BB}$ & 0.8900 \\
$\mathrm{O} 2-\mathrm{C} 1$ & $1.034(15)$ & $\mathrm{N} 1 \mathrm{~B}-\mathrm{H} 1 \mathrm{BC}$ & 0.8900 \\
$\mathrm{~N} 1-\mathrm{H} 1 \mathrm{~A}$ & 0.8900 & $\mathrm{~N} 1 \mathrm{~B}-\mathrm{C} 2 \mathrm{~B}$ & $1.457(17)$ \\
$\mathrm{N} 1-\mathrm{H} 1 \mathrm{~B}$ & 0.8900 & $\mathrm{O} 1 \mathrm{~B}-\mathrm{C} 1 \mathrm{~B}$ & $1.41(2)$ \\
$\mathrm{N} 1-\mathrm{H} 1 \mathrm{C}$ & 0.8900 & $\mathrm{O} 1 \mathrm{~B}-\mathrm{H} 1$ & $1.20(2)$ \\
$\mathrm{N} 1-\mathrm{C} 2$ & $1.492(6)$ & $\mathrm{O} 2 \mathrm{~B}-\mathrm{C} 1 \mathrm{~B}$ & $1.63(4)$ \\
$\mathrm{C} 1-\mathrm{C} 2$ & $1.544(7)$ & $\mathrm{C} 2 \mathrm{~B}-\mathrm{H} 2 \mathrm{~B}$ & 0.9800 \\
$\mathrm{C} 6-\mathrm{O} 4$ & $1.295(6)$ & $\mathrm{C} 2 \mathrm{~B}-\mathrm{C} 1 \mathrm{~B}$ & $1.481(18)$ \\
$\mathrm{C} 6-\mathrm{C} 7$ & $1.486(8)$ & $\mathrm{C} 2 \mathrm{~B}-\mathrm{C} 3 \mathrm{~B}$ & $1.52(3)$ \\
$\mathrm{C} 6-\mathrm{O} 4 \mathrm{~B}$ & $1.345(6)$ & $\mathrm{C} 7 \mathrm{~B}-\mathrm{C} 7 \mathrm{~B}$ & $1.331(17)$ \\
$\mathrm{C} 6-\mathrm{C} 7 \mathrm{~B}$ & $1.437(9)$ & $\mathrm{C} 7 \mathrm{~B}-\mathrm{H} 7 \mathrm{~B}$ & 0.9300 \\
$\mathrm{C} 6-\mathrm{O} 3$ & $1.17(3)$ & $\mathrm{C} 3 \mathrm{~B}-\mathrm{H} 3 \mathrm{BA}$ & 0.9700 \\
$\mathrm{C} 6-\mathrm{O} 3 \mathrm{~B}$ & $1.29(3)$ & $\mathrm{C} 3 \mathrm{~B}-\mathrm{H} 3 \mathrm{BB}$ & 0.9700
\end{tabular}




\begin{tabular}{|c|c|c|c|}
\hline $\mathrm{C} 3-\mathrm{H} 3 \mathrm{~A}$ & 0.9700 & $\mathrm{C} 3 \mathrm{~B}-\mathrm{C} 4 \mathrm{~B}$ & $1.42(3)$ \\
\hline $\mathrm{C} 3-\mathrm{H} 3 \mathrm{~B}$ & 0.9700 & $\mathrm{C} 4 \mathrm{~B}-\mathrm{H} 4 \mathrm{BA}$ & 0.9700 \\
\hline $\mathrm{C} 3-\mathrm{C} 2$ & $1.541(8)$ & $\mathrm{C} 4 \mathrm{~B}-\mathrm{H} 4 \mathrm{BB}$ & 0.9700 \\
\hline $\mathrm{C} 3-\mathrm{C} 4$ & $1.481(10)$ & $\mathrm{C} 4 \mathrm{~B}-\mathrm{C} 5 \mathrm{~B}$ & $1.29(4)$ \\
\hline $\mathrm{C} 2-\mathrm{H} 2$ & 0.9800 & $\mathrm{C} 5-\mathrm{H} 5 \mathrm{~A}$ & 0.9600 \\
\hline $\mathrm{O} 4-\mathrm{H} 4$ & $1.212(7)$ & $\mathrm{C} 5-\mathrm{H} 5 \mathrm{~B}$ & 0.9600 \\
\hline $\mathrm{C} 4-\mathrm{H} 4 \mathrm{~A}$ & 0.9700 & $\mathrm{C} 5-\mathrm{H} 5 \mathrm{C}$ & 0.9600 \\
\hline $\mathrm{C} 4-\mathrm{H} 4 \mathrm{~B}$ & 0.9700 & $\mathrm{C} 5 \mathrm{~B}-\mathrm{H} 5 \mathrm{BA}$ & 0.9600 \\
\hline $\mathrm{C} 4-\mathrm{C} 5$ & $1.586(12)$ & $\mathrm{C} 5 \mathrm{~B}-\mathrm{H} 5 \mathrm{BB}$ & 0.9600 \\
\hline $\mathrm{C} 7-\mathrm{C}^{\mathrm{i}}$ & $1.327(14)$ & $\mathrm{C} 5 \mathrm{~B}-\mathrm{H} 5 \mathrm{BC}$ & 0.9600 \\
\hline $\mathrm{C} 7-\mathrm{H} 7$ & 0.9300 & & \\
\hline $\mathrm{C} 1-\mathrm{O} 1-\mathrm{H} 1$ & $110.8(7)$ & $\mathrm{C} 2 \mathrm{~B}-\mathrm{N} 1 \mathrm{~B}-\mathrm{H} 1 \mathrm{BA}$ & 109.5 \\
\hline $\mathrm{H} 1 \mathrm{~A}-\mathrm{N} 1-\mathrm{H} 1 \mathrm{~B}$ & 109.5 & $\mathrm{C} 2 \mathrm{~B}-\mathrm{N} 1 \mathrm{~B}-\mathrm{H} 1 \mathrm{BB}$ & 109.5 \\
\hline $\mathrm{H} 1 \mathrm{~A}-\mathrm{N} 1-\mathrm{H} 1 \mathrm{C}$ & 109.5 & $\mathrm{C} 2 \mathrm{~B}-\mathrm{N} 1 \mathrm{~B}-\mathrm{H} 1 \mathrm{BC}$ & 109.5 \\
\hline $\mathrm{H} 1 \mathrm{~B}-\mathrm{N} 1-\mathrm{H} 1 \mathrm{C}$ & 109.5 & $\mathrm{C} 1 \mathrm{~B}-\mathrm{O} 1 \mathrm{~B}-\mathrm{H} 1$ & $112.4(17)$ \\
\hline $\mathrm{C} 2-\mathrm{N} 1-\mathrm{H} 1 \mathrm{~A}$ & 109.5 & $\mathrm{~N} 1 \mathrm{~B}-\mathrm{C} 2 \mathrm{~B}-\mathrm{H} 2 \mathrm{~B}$ & 108.1 \\
\hline $\mathrm{C} 2-\mathrm{N} 1-\mathrm{H} 1 \mathrm{~B}$ & 109.5 & $\mathrm{~N} 1 \mathrm{~B}-\mathrm{C} 2 \mathrm{~B}-\mathrm{C} 1 \mathrm{~B}$ & $100.8(18)$ \\
\hline $\mathrm{C} 2-\mathrm{N} 1-\mathrm{H} 1 \mathrm{C}$ & 109.5 & $\mathrm{~N} 1 \mathrm{~B}-\mathrm{C} 2 \mathrm{~B}-\mathrm{C} 3 \mathrm{~B}$ & $109.4(15)$ \\
\hline $\mathrm{O} 1-\mathrm{C} 1-\mathrm{C} 2$ & $113.7(8)$ & $\mathrm{C} 1 \mathrm{~B}-\mathrm{C} 2 \mathrm{~B}-\mathrm{H} 2 \mathrm{~B}$ & 108.1 \\
\hline $\mathrm{O} 2-\mathrm{C} 1-\mathrm{O} 1$ & $131.8(9)$ & $\mathrm{C} 1 \mathrm{~B}-\mathrm{C} 2 \mathrm{~B}-\mathrm{C} 3 \mathrm{~B}$ & $121(2)$ \\
\hline $\mathrm{O} 2-\mathrm{C} 1-\mathrm{C} 2$ & $113.5(9)$ & $\mathrm{C} 3 \mathrm{~B}-\mathrm{C} 2 \mathrm{~B}-\mathrm{H} 2 \mathrm{~B}$ & 108.1 \\
\hline $\mathrm{O} 4-\mathrm{C} 6-\mathrm{C} 7$ & $120.5(4)$ & $\mathrm{C} 6-\mathrm{C} 7 \mathrm{~B}-\mathrm{H} 7 \mathrm{~B}$ & 114.0 \\
\hline $\mathrm{O} 4 \mathrm{~B}-\mathrm{C} 6-\mathrm{C} 7 \mathrm{~B}$ & $119.3(5)$ & $\mathrm{C} 7 \mathrm{~B}^{\mathrm{i}}-\mathrm{C} 7 \mathrm{~B}-\mathrm{C} 6$ & $131.9(4)$ \\
\hline $\mathrm{O} 3-\mathrm{C} 6-\mathrm{O} 4$ & $119(2)$ & $\mathrm{C} 7 \mathrm{~B}-\mathrm{C} 7 \mathrm{~B}-\mathrm{H} 7 \mathrm{~B}$ & 114.0 \\
\hline $\mathrm{O} 3-\mathrm{C} 6-\mathrm{C} 7$ & $120(2)$ & $\mathrm{O} 1 \mathrm{~B}-\mathrm{C} 1 \mathrm{~B}-\mathrm{O} 2 \mathrm{~B}$ & $106(2)$ \\
\hline $\mathrm{O} 3 \mathrm{~B}-\mathrm{C} 6-\mathrm{O} 4 \mathrm{~B}$ & $120(2)$ & $\mathrm{O} 1 \mathrm{~B}-\mathrm{C} 1 \mathrm{~B}-\mathrm{C} 2 \mathrm{~B}$ & $109.0(19)$ \\
\hline $\mathrm{O} 3 \mathrm{~B}-\mathrm{C} 6-\mathrm{C} 7 \mathrm{~B}$ & $120(2)$ & $\mathrm{C} 2 \mathrm{~B}-\mathrm{C} 1 \mathrm{~B}-\mathrm{O} 2 \mathrm{~B}$ & $129(3)$ \\
\hline $\mathrm{H} 3 \mathrm{~A}-\mathrm{C} 3-\mathrm{H} 3 \mathrm{~B}$ & 107.6 & $\mathrm{C} 2 \mathrm{~B}-\mathrm{C} 3 \mathrm{~B}-\mathrm{H} 3 \mathrm{BA}$ & 109.0 \\
\hline $\mathrm{C} 2-\mathrm{C} 3-\mathrm{H} 3 \mathrm{~A}$ & 108.6 & $\mathrm{C} 2 \mathrm{~B}-\mathrm{C} 3 \mathrm{~B}-\mathrm{H} 3 \mathrm{BB}$ & 109.0 \\
\hline $\mathrm{C} 2-\mathrm{C} 3-\mathrm{H} 3 \mathrm{~B}$ & 108.6 & $\mathrm{H} 3 \mathrm{BA}-\mathrm{C} 3 \mathrm{~B}-\mathrm{H} 3 \mathrm{BB}$ & 107.8 \\
\hline $\mathrm{C} 4-\mathrm{C} 3-\mathrm{H} 3 \mathrm{~A}$ & 108.6 & $\mathrm{C} 4 \mathrm{~B}-\mathrm{C} 3 \mathrm{~B}-\mathrm{C} 2 \mathrm{~B}$ & $113(3)$ \\
\hline $\mathrm{C} 4-\mathrm{C} 3-\mathrm{H} 3 \mathrm{~B}$ & 108.6 & $\mathrm{C} 4 \mathrm{~B}-\mathrm{C} 3 \mathrm{~B}-\mathrm{H} 3 \mathrm{BA}$ & 109.0 \\
\hline $\mathrm{C} 4-\mathrm{C} 3-\mathrm{C} 2$ & $114.7(6)$ & $\mathrm{C} 4 \mathrm{~B}-\mathrm{C} 3 \mathrm{~B}-\mathrm{H} 3 \mathrm{BB}$ & 109.0 \\
\hline $\mathrm{N} 1-\mathrm{C} 2-\mathrm{C} 1$ & $113.0(6)$ & $\mathrm{C} 3 \mathrm{~B}-\mathrm{C} 4 \mathrm{~B}-\mathrm{H} 4 \mathrm{BA}$ & 110.0 \\
\hline $\mathrm{N} 1-\mathrm{C} 2-\mathrm{C} 3$ & $110.3(4)$ & $\mathrm{C} 3 \mathrm{~B}-\mathrm{C} 4 \mathrm{~B}-\mathrm{H} 4 \mathrm{BB}$ & 110.0 \\
\hline $\mathrm{N} 1-\mathrm{C} 2-\mathrm{H} 2$ & 108.0 & $\mathrm{H} 4 \mathrm{BA}-\mathrm{C} 4 \mathrm{~B}-\mathrm{H} 4 \mathrm{BB}$ & 108.4 \\
\hline $\mathrm{C} 1-\mathrm{C} 2-\mathrm{H} 2$ & 108.0 & $\mathrm{C} 5 \mathrm{~B}-\mathrm{C} 4 \mathrm{~B}-\mathrm{C} 3 \mathrm{~B}$ & $108(3)$ \\
\hline $\mathrm{C} 3-\mathrm{C} 2-\mathrm{C} 1$ & $109.3(8)$ & $\mathrm{C} 5 \mathrm{~B}-\mathrm{C} 4 \mathrm{~B}-\mathrm{H} 4 \mathrm{BA}$ & 110.0 \\
\hline $\mathrm{C} 3-\mathrm{C} 2-\mathrm{H} 2$ & 108.0 & $\mathrm{C} 5 \mathrm{~B}-\mathrm{C} 4 \mathrm{~B}-\mathrm{H} 4 \mathrm{BB}$ & 110.0 \\
\hline $\mathrm{C} 6-\mathrm{O} 4-\mathrm{H} 4$ & $105(4)$ & $\mathrm{C} 4-\mathrm{C} 5-\mathrm{H} 5 \mathrm{~A}$ & 109.5 \\
\hline $\mathrm{C} 3-\mathrm{C} 4-\mathrm{H} 4 \mathrm{~A}$ & 109.0 & $\mathrm{C} 4-\mathrm{C} 5-\mathrm{H} 5 \mathrm{~B}$ & 109.5 \\
\hline $\mathrm{C} 3-\mathrm{C} 4-\mathrm{H} 4 \mathrm{~B}$ & 109.0 & $\mathrm{C} 4-\mathrm{C} 5-\mathrm{H} 5 \mathrm{C}$ & 109.5 \\
\hline $\mathrm{C} 3-\mathrm{C} 4-\mathrm{C} 5$ & $112.7(8)$ & $\mathrm{H} 5 \mathrm{~A}-\mathrm{C} 5-\mathrm{H} 5 \mathrm{~B}$ & 109.5 \\
\hline $\mathrm{H} 4 \mathrm{~A}-\mathrm{C} 4-\mathrm{H} 4 \mathrm{~B}$ & 107.8 & $\mathrm{H} 5 \mathrm{~A}-\mathrm{C} 5-\mathrm{H} 5 \mathrm{C}$ & 109.5 \\
\hline $\mathrm{C} 5-\mathrm{C} 4-\mathrm{H} 4 \mathrm{~A}$ & 109.0 & $\mathrm{H} 5 \mathrm{~B}-\mathrm{C} 5-\mathrm{H} 5 \mathrm{C}$ & 109.5 \\
\hline $\mathrm{C} 5-\mathrm{C} 4-\mathrm{H} 4 \mathrm{~B}$ & 109.0 & $\mathrm{C} 4 \mathrm{~B}-\mathrm{C} 5 \mathrm{~B}-\mathrm{H} 5 \mathrm{BA}$ & 109.5 \\
\hline $\mathrm{C} 6-\mathrm{C} 7-\mathrm{H} 7$ & 114.8 & $\mathrm{C} 4 \mathrm{~B}-\mathrm{C} 5 \mathrm{~B}-\mathrm{H} 5 \mathrm{BB}$ & 109.5 \\
\hline
\end{tabular}




\begin{tabular}{|c|c|}
\hline $\mathrm{C} 7-\mathrm{C} 7-\mathrm{C} 6$ & $130.4(3)$ \\
\hline $\mathrm{C} 7-\mathrm{C} 7-\mathrm{H} 7$ & 114.8 \\
\hline $\mathrm{H} 1 \mathrm{BA}-\mathrm{N} 1 \mathrm{~B}-\mathrm{H} 1 \mathrm{BB}$ & 109.5 \\
\hline $\mathrm{H} 1 \mathrm{BA}-\mathrm{N} 1 \mathrm{~B}-\mathrm{H} 1 \mathrm{BC}$ & 109.5 \\
\hline $\mathrm{H} 1 \mathrm{BB}-\mathrm{N} 1 \mathrm{~B}-\mathrm{H} 1 \mathrm{BC}$ & 109.5 \\
\hline $\mathrm{O} 1-\mathrm{C} 1-\mathrm{C} 2-\mathrm{N} 1$ & $17.9(14)$ \\
\hline $\mathrm{O} 1-\mathrm{C} 1-\mathrm{C} 2-\mathrm{C} 3$ & $-105.4(12)$ \\
\hline $\mathrm{O} 2-\mathrm{C} 1-\mathrm{C} 2-\mathrm{N} 1$ & $-151.9(12)$ \\
\hline $\mathrm{O} 2-\mathrm{C} 1-\mathrm{C} 2-\mathrm{C} 3$ & $84.9(15)$ \\
\hline $\mathrm{C} 2-\mathrm{C} 3-\mathrm{C} 4-\mathrm{C} 5$ & $-177.9(7)$ \\
\hline $\mathrm{O} 4-\mathrm{C} 6-\mathrm{C} 7-\mathrm{C}^{\mathrm{i}}$ & $-7.7(7)$ \\
\hline $\mathrm{C} 4-\mathrm{C} 3-\mathrm{C} 2-\mathrm{N} 1$ & $-67.1(8)$ \\
\hline $\mathrm{C} 4-\mathrm{C} 3-\mathrm{C} 2-\mathrm{C} 1$ & $57.7(9)$ \\
\hline $\mathrm{O} 4 \mathrm{~B}-\mathrm{C} 6-\mathrm{C} 7 \mathrm{~B}-\mathrm{C} 7 \mathrm{~B}^{\mathrm{i}}$ & $8.4(9)$ \\
\hline
\end{tabular}

$\mathrm{C} 4 \mathrm{~B}-\mathrm{C} 5 \mathrm{~B}-\mathrm{H} 5 \mathrm{BC}$

$\mathrm{H} 5 \mathrm{BA}-\mathrm{C} 5 \mathrm{~B}-\mathrm{H} 5 \mathrm{BB}$

$\mathrm{H} 5 \mathrm{BA}-\mathrm{C} 5 \mathrm{~B}-\mathrm{H} 5 \mathrm{BC}$

$\mathrm{H} 5 \mathrm{BB}-\mathrm{C} 5 \mathrm{~B}-\mathrm{H} 5 \mathrm{BC}$

$\mathrm{N} 1 \mathrm{~B}-\mathrm{C} 2 \mathrm{~B}-\mathrm{C} 1 \mathrm{~B}-\mathrm{O} 1 \mathrm{~B}$

$\mathrm{N} 1 \mathrm{~B}-\mathrm{C} 2 \mathrm{~B}-\mathrm{C} 1 \mathrm{~B}-\mathrm{O} 2 \mathrm{~B}$

$\mathrm{N} 1 \mathrm{~B}-\mathrm{C} 2 \mathrm{~B}-\mathrm{C} 3 \mathrm{~B}-\mathrm{C} 4 \mathrm{~B}$

$\mathrm{C} 2 \mathrm{~B}-\mathrm{C} 3 \mathrm{~B}-\mathrm{C} 4 \mathrm{~B}-\mathrm{C} 5 \mathrm{~B}$

$\mathrm{C} 1 \mathrm{~B}-\mathrm{C} 2 \mathrm{~B}-\mathrm{C} 3 \mathrm{~B}-\mathrm{C} 4 \mathrm{~B}$

$\mathrm{C} 3 \mathrm{~B}-\mathrm{C} 2 \mathrm{~B}-\mathrm{C} 1 \mathrm{~B}-\mathrm{O} 1 \mathrm{~B}$

$\mathrm{C} 3 \mathrm{~B}-\mathrm{C} 2 \mathrm{~B}-\mathrm{C} 1 \mathrm{~B}-\mathrm{O} 2 \mathrm{~B}$

$\mathrm{O} 3-\mathrm{C} 6-\mathrm{C} 7-\mathrm{C} 7^{\mathrm{i}}$

$\mathrm{O} 3 \mathrm{~B}-\mathrm{C} 6-\mathrm{C} 7 \mathrm{~B}-\mathrm{C} 7 \mathrm{~B}^{\mathrm{i}}$
109.5

109.5

109.5

109.5

147 (3)

$-83(4)$

$-173(2)$

$144(3)$

$71(3)$

$-92(3)$

$38(4)$

$-180(3)$

$174(3)$

Symmetry code: (i) $x,-y+3 / 2, z$.

Hydrogen-bond geometry $\left(\AA,{ }^{o}\right)$

\begin{tabular}{lllll}
\hline$D-\mathrm{H} \cdots A$ & $D-\mathrm{H}$ & $\mathrm{H} \cdots A$ & $D \cdots A$ & $D-\mathrm{H} \cdots A$ \\
\hline $\mathrm{N} 1-\mathrm{H} 1 A \cdots \mathrm{O} 2^{\mathrm{ii}}$ & 0.89 & 1.94 & $2.807(8)$ & 165 \\
$\mathrm{~N} 1-\mathrm{H} 1 B \cdots \mathrm{O} 3$ & 0.89 & 2.08 & $2.92(4)$ & 157 \\
$\mathrm{~N} 1-\mathrm{H} 1 C \cdots \mathrm{O} 3^{\text {iii }}$ & 0.89 & 1.90 & $2.79(4)$ & 178 \\
$\mathrm{O} 1-\mathrm{H} 1 \cdots \mathrm{O} 1^{\mathrm{iv}}$ & $1.28(1)$ & $1.28(1)$ & $2.568(13)$ & $180(1)$ \\
$\mathrm{O} 4-\mathrm{H} 4 \cdots \mathrm{O} 4{ }^{\mathrm{i}}$ & $1.21(1)$ & $1.21(1)$ & $2.418(9)$ & $173(8)$ \\
\hline
\end{tabular}

Symmetry codes: (i) $x,-y+3 / 2, z$; (ii) $-x+1 / 2,-y+1, z-1 / 2$; (iii) $x-1 / 2, y,-z+1 / 2$; (iv) $-x+1,-y+1,-z+1$. 